San Jose State University

SJSU ScholarWorks

Master's Theses

Master's Theses and Graduate Research

1990

\title{
Distribution, behavior, and food habits of harbor porpoises (Phocoena phocoena) in Monterey Bay
}

Eric J. Dorfman

San Jose State University

Follow this and additional works at: https://scholarworks.sjsu.edu/etd_theses

\section{Recommended Citation}

Dorfman, Eric J., "Distribution, behavior, and food habits of harbor porpoises (Phocoena phocoena) in Monterey Bay" (1990). Master's Theses. 44.

DOI: https://doi.org/10.31979/etd.bb4q-cksy

https://scholarworks.sjsu.edu/etd_theses/44

This Thesis is brought to you for free and open access by the Master's Theses and Graduate Research at SJSU ScholarWorks. It has been accepted for inclusion in Master's Theses by an authorized administrator of SJSU ScholarWorks. For more information, please contact scholarworks@sjsu.edu. 


\section{INFORMATION TO USERS}

The most advanced technology has been used to photograph and reproduce this manuscript from the microfilm master. UMI films the text directly from the original or copy submitted. Thus, some thesis and dissertation copies are in typewriter face, while others may be from any type of computer printer.

The quality of this reproduction is dependent upon the quality of the copy submitted. Broken or indistinct print, colored or poor quality iilustrations and photographs, print bleedthrough, substandard margins, and improper alignment can adversely affect reproduction.

In the unlikely event that the author did not send UMI a complete manuscript and there are missing pages, these will be noted. Also, if unauthorized copyright material had to be removed, a note will indicate the deletion.

Oversize materials (e.g., maps, drawings, charts) are reproduced by sectioning the original, beginning at the upper left-hand corner and continuing from left to right in equal sections with small overlaps. Each original is also photographed in one expossure and is included in reduced form at the back of the book.

Photographs included in the original manuscript have been reproduced xerographically in this copy. Higher quality 6" x 9" black and white photographic prints are available for any photographs or illustrations appearing in this copy for an additional charge. Contact UMI directly to order.

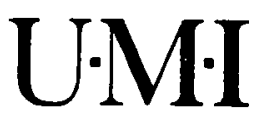

University Microlilms International

A Bell \& Howell Information Company

300 North Zeeb Road. Ann Arbor. MI 48106-1346 USA

$313 / 761-4700 \quad 800 / 521-0600$ 

Distribution, behavior, and food habits of harbor porpoises (Phocoena phocoena) in Monterey Bay

Dorfman, Eric Joshua, M.S.

San Jose State University, 1990 


\title{
DISTRIBUTION, BEHAVIOR, AND FOOD HABITS \\ OF HARBOR PORPOISES (Phocoena phocoena) \\ IN MONTEREY BAY
}

\author{
A Thesis \\ Presented to \\ The Faculty of Moss Landing Marine Laboratories \\ San Jose State University \\ In Partial Fulfillment \\ of the Requirements for the Degree \\ Master of Science
}

By

Eric J. Dorfman

November, 1990 
APPROVED FOR MOSS LANDING ARINE LABORATORIES

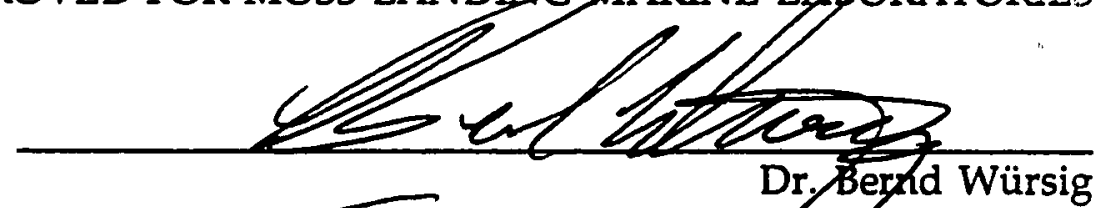
Samert. Nawey

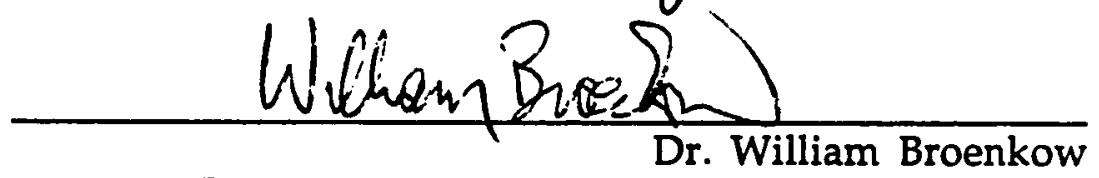

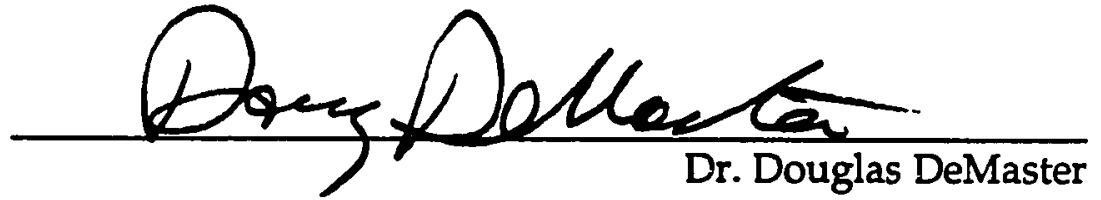

APPROVED FOR THE UNIVERSITY

H. Sou Dewandowat 


\section{ABSTRACT \\ DISTRIBUTION, BEHAVIOR AND FOOD HABITS \\ HARBOR PORPOISES (Phocoena phocoena) \\ IN MONTEREY BAY \\ by Eric J. Dorfman}

Behavior and distribution of harbor porpoises (Phocoena phocoena) were observed from ship, January 1989 through June 1990. During the first twelve months, data on sea surface temperature and water clarity were taken. Harbor porpoises were periodically associated with warmer waters and areas north of Monterey Submarine Canyon. The ratio of adult to juvenile harbor porpoises fluctuated significantly over the year. All individuals engaged in milling behavior significantly more in internal-wave produced surface slicks and traveled significantly more in non-slick areas. Milling behaviors may be indicative of feeding, and conspicuous aerial behaviors may serve a social function.

A new index (percent caloric contribution) is presented for ranking prey items found in cetacean stomachs, based on nutritional value, as well as amount of food consumed. This ranking system is substantially different from IRI, and more appropriate for use with marine mammals. 


\section{ACKNOWLEDGEMENTS}

This project could not have begun, much less been completed, without the generous assistance of a great many people. Dr. Bernd Würsig, my thesis advisor and friend, has given me guidence and much encouragement, despite the long distance from Moss Landing to Galveston. The contributions of the other members of my thesis committe were also invaluable. Dr. James Harvey gave substantial time and advice, especially with the work in Chapter 2. Dr. William Broenkow gave considerable insight into the problems of field oceanography, and was willing to devote his time to even basic questions. Dr. Douglas DeMaster provided the innitial impetus for this project, and gave support, both financially and in the form of direction.

A great number of people helped with data collection. Principal among these were Tony Bennett, Patience Browne, Mike Feinholz, Leslie Long, Daniela Maldini, John Mason, Tom Norris and Cathy Rathbun. Tracy Thomas, who drove the boat, sometimes at short notice, gave sound advice on the limitations of time and equipment.

I thank Rangers Dave Dixon, Bill Hambaro, and Dave Rodriguez of the California Department of Parks and Recreation, Marina District, who were instrumental the recovery (and delivery) of a number of beach cast harbor porpoises.

Sheila Baldridge was always available for last-minute library searches and ongoing encouragement, and Gail Johnston did much to streamline the educational process. Lynn McMasters's instruction and time resulted in 
I also thank Alan Baldridge, Aleta Hohn, Thomas Jefferson, Susan McBride, Dion Oxman, Steve Trumble and Marilyn Yuen for helpful criticism during the project and successive thesis drafts. My good friends Mark Langner and Lynn Inouye provided sampling assistance and camaraderie throughout this project.

This project was funded in part by grants from the Earl and Ethyl Myers Foundation and The Packard Graduate Student Fund. 


\section{TABLE OF CONTENTS}

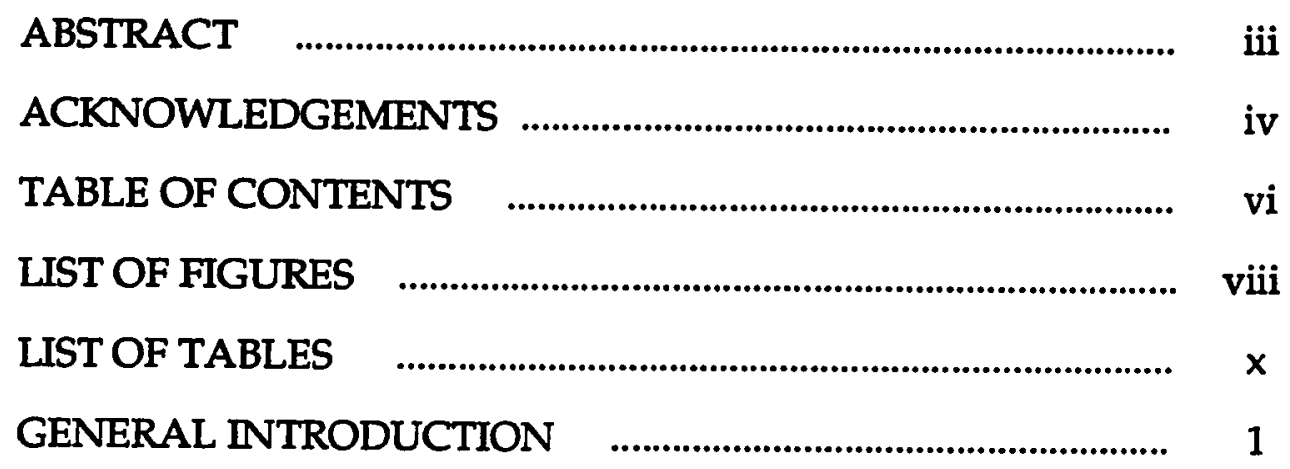

CHAPTER 1: Distribution and Behavior: Temporal,

Physiograophic and Oceanographic Factors $\quad \ldots . . . \quad 2$

INTRODUCTION $\quad$...................................................................... 2

MATERIALS AND METHODS $\quad$................................................. 6

The Study Area

Transects …............................................................... 8

Oceanographic Data Collection $\quad$.......................................... 8

Behavioral Observations $\quad$................................................... 9

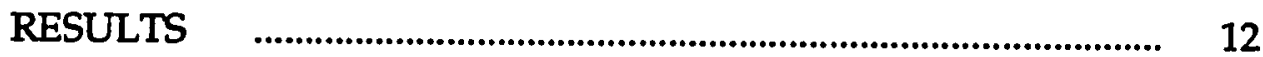

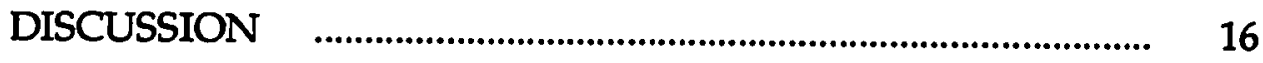

Distribution _....................................................................... 17

Behavior ........................................................................ 21

CHAPTER 2: A Comparison of Methods Used in the Analysis of Cetacean Stomachs $\quad$............................... 25

INTRODUCTION $\quad$...................................................................... 25 
MATERIALS AND METHODS $\quad$............................................. 26

RESULTS

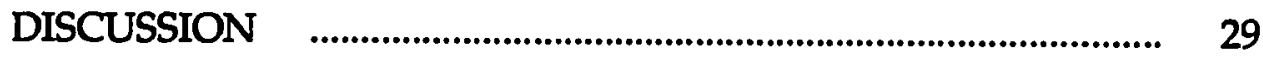

GENERAL CONCLUSIONS

Distribution

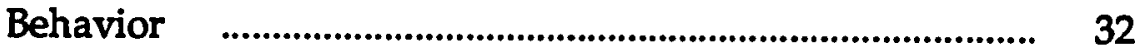

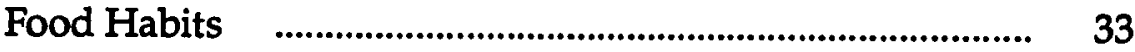

FIGURES

TABLE 1

TABLE 2

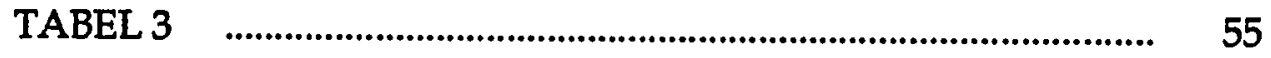

APPENDIX 


\section{LIST OF FIGURES}

Figure

Page

1. Measurements of temperature and Secchi depth were taken at thirteen stations along the transect.

2. An assignment of milling (A) was given if a total of three surfacings were observed with different orientations to one another, and traveling (B) assigned if three surfacings were in the same orientation. Observations of pop splashing $(\mathrm{C})$ were used as one indicator of boat disturbance. Aerial behaviors (D) consisting of rotation on the longitudinal axis were observed, and anterior and posterior flips were common.

3. The dramatic drop in temperature on 11 July (A, designated by arrow) is supported by data from the Monterey Bay Aquarium (MBA) at $7 \mathrm{~m}$ below MLLW (B), which shows a similar temperature decrease for that day (also designated by an arrow).

4. Comparison of average temperature per cruise (A), average Secchi depth per cruise (B) and number of sightings per hour per cruise (C), over three oceanographic periods. Bars reflect one Standard Error.

5. Average pod size per cruise and number of pods per cruise were significantly correlated ( $r s=0.610, n=33, P<0.05$ ).

6. Sightings of harbor porpoises over all periods (A), during the upwelling period Jan. 1989 through Jul. 1989 (B), the oceanic period Aug. 1989 through Oct. 1989 (C), and the Davidson Current period Nov. 1989 through Feb. 1990 (D).

7. Average number of sightings per cruise and average surface temperature per cruise were significantly correlated (rs $=0.656, \mathrm{df}=19, \mathrm{P}<0.05$ ).

8. Average number of sightings of sub-adult harbor porpoises varied significantly over season $(\mathrm{H}=16.693, \mathrm{df}=3, \mathrm{P}<0.05)$. 
9. Milling was observed significantly mere often in surface slicks (Chi-square $=10.22, \mathrm{df}=1, \mathrm{P}<\mathrm{u} .05$ ), and travelling more often in non-slick areas (Chi- square $=106.33, \mathrm{df}=1, \mathrm{P}<0.05$ ).

10. Aerial behavior fluctuated significantly over time $(\mathrm{H}$ $=4.746, \mathrm{df}=3, \mathrm{P}<0.05$ ).

11 Longitudinal measurements of otoliths (A) and squid beaks (B, after Clark 1986) were taken for all found in harbor porpoise stomachs.

12 Eight species found in harbor porpoise stomachs, ranked by percent caloric contribution (\%CC), and Index of Relative Importance (IRI, Pinkas et al. 1971). 


\section{LIST OF TABLES}

Table

Page

1. Prey consumed by harbor porpoises in this study, $\mathrm{n}=19$ stomachs. When values were unobtainable, substitutes were taken from the taxonomically closest species.

2. Data on harbor porpoises used in this study. Specimens came from Seascape (Sscp), Pajaro Dunes (PD), Moss Landing State Beach (MLSB), Seacliff State Beach (Sclf SB), Marina State Beach (MSB), Salinas River State Beach (SRSB), Aptos, Santa Cruz Harbor (SCH), Sunset State Beach (SSB) and La Selva Beach (LSB). Standard length in $\mathrm{cm}$.

3. Percent caloric contribution (\%CC), index of relative importance (IRI) for eight species found in harbor porpoise stomachs ( $n=19$ stomachs). 


\section{GENERAL INTRODUCTION}

The inaccessibility of most cetaceans in their natural environment precludes detailed study of many topics common for terrestrial mammals. Detailed descriptions of social systems such as those of some terrestrial mammals are largely impossible for wild cetaceans. Inferences based on changes in distribution concurrent with fluctuations in environmental variables are often effective substitutes for more direct observations. This is especially true of harbor porpoises (Phocoena phocoena, L.) in Monterey Bay, which demonstrate few conspicuous behaviors and are wary of boats. ${ }^{1}$ Periodically high incidental catches of harbor porpoises by halibut set-nets increase the value of data on distribution, and distrbutional influences.

This study combined two aspects of environmental influences on harbor porpoises in Monterey Bay. The first related harbor porpoises' seasonal patterns of movement with hydrographic and physiographic factors. Behavioral states were also investigated as possible indicators of habitat utilization. The second part of this study investigated the importance to harbor porpoises of various prey items. It was a refinement of a technique for stomach content analysis Index of Relative Importance (IRI, Pinkas et al. 1971), used previously to assess harbor porpoises feeding in the area (Sekiguchi 1987). In this study, prey species were ranked by order of importance using percent caloric contribution (\%CC), an index which incorporates prey species caloric content. This was compared with IRI (Pinkas et. al 1971), used previously and sometimes inappropriately.

${ }^{1}$ Kinze (pers. comm.) reports, however, that harbor porpoises in the Baltic are not fearful of boats. 


\section{CHAPTER 1}

Distribution and Abundance of Harbor Porpoise: Temporal, Physiographic and Oceanographic Factors

\section{INTRODUCTION}

Growing concern for the population status of the world's small cetaceans has prompted an increase in research geared to minimize their interactions with humans. To predict impact and extent of human interaction with cetaceans (or any organism), basic information relating life history and physical environment is essential. A small but growing body of knowledge exists linking cetacean abundance with physiographic features (Gaskin 1968; Hui 1979; Au and Perryman 1985; Hui 1985; Smith and Gaskin 1985; Ljungblad et al. 1988). Cetaceans were found frequently in areas where physical factors combine to increase food availability.

The harbor porpoise (Phocoena phocoena) averages $1.5 \mathrm{~m}$ in length and $55 \mathrm{~kg}$ in mass (Gaskin et al.1974). It is distributed throughout the coastal waters of the European Atlantic, Asian Pacific, eastern and western North America, southern Greenland, Iceland, and the Baltic Sea (Gaskin et al. 1974). The species was divided into four distinct populations (eastern Pacific, western Atlantic, eastern Atlantic, Black Sea - Sea of Azov stocks), based on skull morphometrics (Yurick and Gaskin 1987).

In the Bay of Fundy, Smith and Gaskin (1985) used a habitat index to determine environmental influences on distribution of females with calves, and Watts and Gaskin (1983) extended the analysis to the entire population. 
Harbor porpoises were associated with environmental conditions that were indicative of prey concentrations, including deep (to $100 \mathrm{~m}$ ), clear waters, and presence of Calanus sp.

Harbor porpoises which were radio-tagged (Read and Gaskin 1985), and these studies reveal two activity states, the predominant being an active one, punctuated by the second state of reduced or no activity. Daily home ranges were from $15-20 \mathrm{~km}^{2}$. Harbor porpoises did not feed continuously, which Read and Gaskin (1985) suggested might be due to high feeding efficiency. Harbor porpoises were inactive at night, possibly due to diurnal changes in prey abundance (Read and Gaskin 1985). These data support the hypothesis that harbor porpoises metabolic rate similar to equal-sized terrestrial animals, as suggested by Kanwisher and Sundnes (1965), and consequentially may not require prolonged feeding bouts and areas of high prey concentration. Yasui and Gaskin (1986) supported this with a model of harbor porpoise metabolism, which estimated a non-pregnant adult consumed approximately $3.5 \%$ of its total body weight per day.

Read (1990a and 1990b) suggested female harbor porpoises produced approximately two offspring, based on an average estimated life span of seven years (although a maximum of 13 years has been reported (Gaskin and Blair 1977)), and an age of first reproduction of approximately five years. This supports the statement by Gaskin et al. (1984) that reproductive flexibility of harbor porpoises is "likely to be limited."

The majority of work conducted in central California used dead animals (Morejohn et al. 1978 Jones 1981; and Sekiguchi 1987) for analysis of food habits, or made observations from the air (Barlow 1987) or land 
(Sekiguchi 1987; Silber and Smultea in press). Despite these studies, harbor porpoise natural history in Monterey Bay is still little known.

Because harbor porpoises consume highly mobile organisms (Jones 1981), they may increase foraging ability by following schools of prey. Different portions of the Monterey Bay also differ with respect to depth, surface temperature, turbidity, standing stock of phytoplankton, and exposure to wind. Any of these may influence harbor porpoises, either directly by reducing thermal stress or minimizing contact with predators, or indirectly by increasing prey availability. Hence, these factors might be used effectively as indicators of suitable harbor porpoise habitat.

Behavior may be an indicator of habitat use, beyond that given by mere presence, thus allowing the observation scale to become finer. As an example, Silber and Smultea (in press) examined behavioral differences between harbor porpoises sighted within surface slicks and those sighted outside. Surface slicks are calm patches of water visible on rippled seas during conditions when winds are less than $6 \mathrm{~km} / \mathrm{hr}$ (Ewing 1950). Slicks are caused by the ripple-damping action of a surface film of naturally-occurring organic matter, and are manifestations of differential zones of surface film compaction. Compaction of film molecules may be caused by horizontal convergence due to wind stress, or by horizontally convergent water flow (Ewing 1950).

Surface slicks concentrate plankton, attracting small planktivorous fishes (Kingsford and Choat 1986; Shanks and Wright 1987), which may attract harbor porpoises to these areas of prey concentration. Silber and Smultea (in press) found harbor porpoises to engage more often in behaviors associated 
with feeding when in surface slicks, whereas no difference was detected for porpoises observed outside slicks. Thus, harbor porpoises may feed primarily in surface slicks and engage in other activities in non-slick areas.

The hypothesis tested was that harbor porpoise behavior and distribution was related to temperature, water clarity, and bathymetry of the nearshore environment in Monterey Bay, and changed seasonally. Harbor porpoise abundance, distribution and behavior was explored relative to oceanographic season, sea surface temperature, depth, and mixing and standing stock of phytoplankton as indicated by Secchi depth. The work of Silber and Smultea (in press) was re-examined, using data collected from ship-board observations. It is hoped that these data will increase the ability to predict harbor porpoise movements in other areas of its range. 


\section{MATERIALS AND METHODS}

Study Area

Research was conducted in Monterey Bay, an open embayment of 59,200 hectares. Monterey Bay is primarily shallow, 80 percent being at depths less than 180 meters. The dominating topographical feature, however, is the Monterey Submarine Canyon, which attains depths of up to 900 meters at the mouth of the bay (Fig. 1).

Broenkow and Smethie (1978) identified terrestrial runoff, sewage outfalls, and vertical mixing as sources of surface water in Monterey Bay. Additionally, they estimated a near-surface residence time of 6 days from temperature, nutrients, sewage-derived ammonia , and freshwater replacement. Under non-drought conditions, five major streams entering the bay have a combined mean annual discharge as much as $1.85 \times 10^{6} \mathrm{~m}^{3}$ day $^{-1}$, with the Salinas River contributing about $55 \%$, the Pajaro River about 20\%, and the San Lorenzo River about 18\% (Broenkow and Smethie 1978). Prevailing dry conditions during this study undoubtedly lessened fresh water discharge into Monterey Bay. Broenkow and Smethie (1978) suggested that deep canyon water was brought to the surface by a combination of internal tides in the canyon and subsequent vertical mixing. Ticial discharge from Elkhorn Slough also may influence Bay water characteristics of Monterey Bay.

Current meter observations reveal a net northerly flow in nearshore Monterey Bay approximately two-thirds of the time (Lasley 1977). Breaker and Broenkow (1989) showed upwelling to occur south of Monterey Bay, in 
Big Sur. Nutrient-rich water enters Monterey Bay from around the Monterey Peninsula and flows northward parallel to the coast, exiting the bay at Pt. Santa Cruz in the north. Chlorophyll-a decreases as the water travels north (Lasley 1977), consistent with the statement of Briggs and Chu (1987) that in areas downstream of upwelling energy transfers up trophic levels, resulting in an observed drop in chlorophyll.

The marine environment of Monterey Bay is largely controlled by the California Current system, the region of the wind-driven North Pacific gyre which flows southwesterly along the west coast of North America. The strong northerly and northwesterly winds occurring in spring and summer cause surface water to be transported offshore under the influence of the Coriolis force. Cool, nutrient-rich subsurface water, probably from a depth of less than 200 meters, rises to replace the water moved offshore. This windinduced upwelling is an important mechanism for returning nutrients to the photic zone. (Broenkow and Smethie 1978)

Bolin and Abbott (1963) divided the seasons of Monterey Bay into three periods, based on temperature and salinity. These were the Davidson current period (November to February), characterized by southerly winds and an abrupt decrease in surface temperature and low salinity; the upwelling period (February to September) marked by lowest surface temperatures and high salinities; and the oceanic period, in which surface temperatures reach the high point of the year and salinities rise slightly. These patterns vary from year to year. During this study, August temperatures were similar to the oceanic period, and were considered this type. Schrader (1980) related the annual cycles of phytoplankton abundance to this hydrographic cycle. He 
found a positive correlation of species diversity with depth of the mixed layer, which he suggested may reflect introduction of new species into the mixed layer from below the thermocline.

Transects

Harbor porpoises were observed on strip transects of $500 \mathrm{~m}$ width. Two observers divided the field of view at a line extending forward from the bow. Thirty-six cruises were conducted from January 1989 through June 1990 (Appendix). Cruises for observation, and not for oceanographic data ran from Moss Landing to Seacliff State Beach along the $10 \mathrm{~m}$ contour.

\section{Oceanographic Data Collection}

Measurements of temperature and water clarity were taken on 20 transects from January 1989 through February 1990. These followed the $10 \mathrm{~m}$ contour from Moss Landing to Fort Ord, out to the $20 \mathrm{~m}$ contour, back to Moss Landing, continuing on to Seacliff State Beach on the $10 \mathrm{~m}$ contour, out to $20 \mathrm{~m}$, following the line back to Moss Landing (Fig 1). These cruises were run from January 1989 through February 1990. The boat stopped at 13 stations for approximately 3 minutes each. Measurements of sea surface temperature, to the nearest tenth of a degree, were taken with a bucket thermometer. Measurements of water clarity were taken with a Secchi disk, read to the nearest half meter. Beaufort sea state was also noted at each station. 
Differences in sea surface temperature among stations were analyzed with Mann-Whitney statistics. Secchi depth north versus south of the Monterey Submarine Canyon was tested with a Mann-Whitney statistic, and a Kruskal-Wallis test to analyze differences between stations. Differences in behavioral state between ocean surface type, depth, temperature and clarity were tested with $\mathrm{Chi}^{2}$ statistics.

Behavioral Observations

Observations of harbor porpoise distribution and behavior were made from the R.V. Ed Ricketts, a 10.6-meter New England lobster trawler, operated by Moss Landing Marine Laboratories. Observations were made 3.5 meters above sea surface in Beaufort sea states of 3 or less. Because pods were usually observed for only a short period (approximately $\mathbf{3 0}$ seconds), individual behaviors were rarely visible. Instead, pods were assigned a behavioral state, based on orientation of individuals.

Total number of surfacings were combined to establish a pod's behavioral state, (e.g. two individuals surfacing twice each during an observation were counted as four surfacings). A minimum of three surfacings was required to assign a behavioral state to the pod (i.e. a minimum combination of either three individuals surfacing once or one individual surfacing three time). A pod was defined as a group of individuals within three body lengths of one another. Behavioral states were similar to those used by Silber and Smultea (in press), to describe the same population of harbor porpoises. 
Milling was defined as three or more surfacings of different orientation (Fig. 2). Milling included variable, non-acrobatic behaviors, such as resting at the surface, pursuit of fishes, and attraction to the boat, as evidenced by rapid approaches and following in the stern wake.

Traveling was three or more surfacings of the same orientation (Fig. 2). No distinction was made between slow and fast travel, unless a response to the boat was detected. During travel, $10 \%$ or less of the porpoises' body broke the surface. Milling and traveling were considered to be mutually exclusive.

In addition to behavioral state, conspicuous behaviors were recorded. These were thought to be indicative of increased excitement level, due either to human disturbance or immediate environmental factors (e.g. social or prey- related).

Response to the Boat was an abrupt change in activity or direction as the boat approached. More severe responses were characterized by increased swimming velocity and pop-splashing (Fig. 2), described by Taylor and Dawson (1984).

Aerial Behaviors were characterized by energetic leaps, twists and porpoising, in which 50-100\% of the body broke the water's surface (Fig. 2). Although responses to the boat and aerial behaviors were considered to be 
mutually exclusive, land-based observations indicated that harbor porpoises pop splash during periods with no human activity discernible (pers. obs.).

Because behavior of an individual porpoise within a pod was not independent of the behavior other pod members, analysis could not be applied to individuals. Instead, analyses were based on number of sightings. A sighting was defined as any observation of harbor porpoises, regardless of number. Number of sightings per hour per cruise, was tested for seasonality using Mann-Whitney and Kruskal-Wallis tests, and was tested for correlation with oceanographic parameters using Spearman rank correlation.

The relationship of aerial behaviors to behavioral state was tested with a Spearman ranked correlation. Aerial behaviors performed by different age classes were not analyzed statistically, because juvenile harbor porpoises were not observed engaging in aerial activity.

A study was conducted to assess possible error in boat observations.

One or two observers on a $95 \mathrm{~m}$ cliff-top counted pods, noted behaviors, and recorded whether or not the pod was in a slick. Boat observers gathered current data on similar parameters. Shore and boat observers were in radio communication with one another, but did not confer on results, to avoid possible sampling biases. Because individual pods were generally seen simultaneously only long enough for both sets of observers to make pod size counts, concurrent data on behavioral state and slick were limited. For this reason, whereas pod counts were analyzed with Wilcoxon sign-rank test, other data taken for verification were tested with $\mathrm{Chi}^{2}$ statistics, based on observational proportions. 


\section{RESULTS}

The upwelling period, consistent with Bolin and Abbott (1963), was characterized by moderate temperatures, rising toward the end of the period. A dramatic decrease in temperature was observed on 11 July during a census and at the Monterey Bay Aquarium (Fig. 3). By the end of this period, surface water temperature had risen sufficiently north of the Monterey Submarine Canyon to create significant differences between the two halves of the Bay. Secchi depth fluctuated considerably during this time.

During the oceanic period, surface water temperatures reached a maximum, and greater differences were observed between temperatures the areas north and south of the Monterey Submarine Canyon.

Surface water temperatures during the Davidson Current period remained consistent with those described by Bolin and Abbott (1963), declining rapidly to the lowest point in the year. No differences between surface temperatures north versus south of the canyon were observed during the Davidson Current period.

Over all seasons, Secchi depth was significantly higher south of the Monterey Submarine Canyon $(\underline{\underline{U}}=7271.5, \underline{Z}=50.11, \underline{P}<0.001$ ). Significant differences in Secchi depth were also found between stations $\underline{H}=58.731, \underline{\mathrm{df}}=$ $12, \underline{\mathrm{P}}<0.001)$. During the upwelling period, harbor porpoise numbers fluctuated substantially (Fig. 4). No differences in harbor porpoise distribution were found, either by depth or north-south location $(P>0.05)$. During this time aerial behaviors were most common, occurring somewhat before the highest pulse of sightings. During the Davidson Current period, 
more harbor porpoises were found in the area north of the canyon than south. By December, the adult population was completely replaced by subadults, and incidence of aerial behaviors had declined to zero (Fig. 8).

Average pod size per cruise and number of sightings per cruise were also significantly correlated $\left(\underline{r}_{s}=0.610, \underline{n}=33, \underline{P}<0.05 ;\right.$ Fig. 5). Cruise legs north of Monterey Submarine Canyon were approximately twice as long as southern legs, therefore sightings per hour were used when comparing the two areas. Significantly more harbor porpoises per hour were observed on the northern than southern legs $\left(\underline{U}^{\prime}=336.0, \underline{Z}=7.66, \underline{P}<0.05\right)$. Number of harbor porpoise per hour over oceanographic season were not significant difference during the upwelling period $\left.\underline{U}^{\prime}=37.0, \underline{P}>0.05\right)$. Significant differences in number of sightings north and south of the canyon did, however, exist during both the oceanic and Davidson Current periods (Fig. 6).

Sea surface temperatures were significantly higher north of the canyon during the upwelling and oceanic periods $\underline{U}^{\prime}=30.0, \underline{P}<0.05, \underline{U}^{\prime}=29.0, \underline{P}<$ 0.05 , respectively). No differences in average surface water temperature were observed north versus south of the canyon during the upwelling period $\underline{U}^{\prime}=$ $27.5, \underline{P}>0.05)$

Water clarity was not significantly different north versus south of the canyon in any season $\underline{U}^{\prime}=22.5$ (upwelling), $\underline{U}^{\prime}=23.5$ (oceanic), $\underline{U}^{\prime}=28$ (Davidson Current), $\underline{P}>0.05$ in all cases). Water clarity also was not different among seasons, using all transects $(\underline{H}=1.603, \mathrm{df}=2, \underline{P}>0.05)$. Over all seasons, however, there was a significant difference in water clarity north versus south of the canyon $\left(\underline{U}^{\prime}=7271.5, \underline{Z}=50.11, \underline{P}<0.05\right)$. Individual 
stations differed among one another, independent of season $\underline{H}=58.731, \mathrm{df}=$ $12, \underline{P}<0.05)$.

Sightings of harbor porpoises over all cruises were positively correlated with average surface temperature $\left(\underline{r}_{s}=0.656, \underline{\mathrm{df}}=19, \underline{\mathrm{P}}<0.05 ;\right.$ Fig. 7$)$, but Secchi depth and harbor porpoise sightings were not correlated significañity $\left(\underline{r}_{s}=0.162, \underline{\mathrm{df}}=19, \underline{\mathrm{P}}>0.05\right)$. Secchi depth measured at the Moss Landing Harbor mouth during incoming versus outgoing tides demonstrated significant differences $(t=2.816, \underline{\mathrm{df}}=11, \underline{\mathrm{P}}<0.05)$.

More harbor porpoises were at $10 \mathrm{~m}$ than $20 \mathrm{~m}\left(\underline{U}^{\prime}=357.5, \underline{P}<0.05\right)$, when measured over all seasons. This difference was not significant during the upwelling period $\left(\underline{U}^{\prime}=26, \underline{P}>0.05\right)$, but was significant during the oceanic and Davidson Current periods $\left(\underline{U}^{\prime}=49, \underline{P}<0.05 ; \underline{U^{\prime}}=43, \underline{P}<0.05\right.$, respectively).

Sightings of juvenile harbor porpoises fluctuated significantly during four oceanographic periods (upwelling 1989, oceanic 1989, Davdison Current 1989-90 and upwelling 1990) measured $(\underline{H}=16, d f=3, \underline{P}<0.05$; Fig. 8). Juveniles were sighted most often during the Davidson Current period.

Harbor porpoises, irrespective of age, spent significantly more time milling while in slicks $\left(\underline{C h i}^{2}=24.93, \underline{\mathrm{df}}=1, \underline{\mathrm{P}}<0.05\right)$ and more time traveling in non-slicked areas ( $\underline{\mathrm{Chi}}^{2}=79.13, \underline{\mathrm{df}}=1, \underline{\mathrm{P}}<0.05 ;$ Fig. 9). Pod size estimates as observed from cliff-top was not significantly different with that observed from the boat (Wilcoxon $\underline{Z}=-0.92, \underline{P}>0.05$ ), and observations of milling and traveling were not significantly different between the two sighting locations $\left(\underline{\mathrm{Chi}}^{2}=0.571, \underline{\mathrm{df}}=1, \underline{\mathrm{P}}>0.05\right)$. Location of harbor porpoises in slick versus 
non-slick also were not significantly different between observations from cliff-top and boat $\left(\underline{C h i}^{2}=0.833, \underline{\mathrm{df}}=1, \underline{P}>0.05\right)$.

The proportion of total sightings counted as milling was not significantly different among seasons $\underline{H}=4.746, \underline{d f}=3, \underline{P}<0.05)$, nor was proportion of milling different between adults and sub-adults $t_{s}=0.004, \underline{\mathrm{df}}=$ $1, \underline{P}>0.05)$. Incidence of conspicuous aerial behaviors was not significantly correlated to frequency of harbor porpoise sightings $\left(\underline{r}_{s}=0.383, \underline{\mathrm{df}}=21, \underline{\mathrm{P}}>\right.$ 0.05). Frequency of aerial behaviors was not different between milling or traveling $\left(\mathrm{Chi}^{2}=0.0005, \underline{\mathrm{df}}=1, \underline{\mathrm{P}}>0.05\right)$, or between in slick and non-slick: water $\left(\mathrm{Chi}^{2}=0.233, \mathrm{df}=1, \mathrm{P}>0.05\right)$. Incidence of aerial behavior did, however, vary significantly among seasons $(\underline{H}=7.463, \underline{d f}=2, \underline{P}>0.05)$; aerial behaviors were most abundant during the oceanic period, and fewest during the Davidson current period (Fig. 10). No juveniles were observed engaged in aerial behaviors. Maximum sightings of aerial behaviors occurred just prior to peak porpoise observations, and demonstrated no obvious relationship with either temperature or water clarity. 


\section{DISCUSSION}

Broenkow (pers. comm.) suggested that annual or daily variability may be greater than overall trends associated with the three-season pattern developed by Bolin and Abbot (1963). Surface temperatures in 1989/1990 were consistent with Bolin and Abbott (1963), and differences among seasons indicate that, at least in the 1989/1990 field season, some validity exists in the seasonal divisions. Harbor porpoises also are probably influenced more by oceanographic conditions than by the solar effects, so divisions based on hydrography are appropriate.

Secchi depth may relate to conditions which effect harbor porpoises in different ways. Being indicative of chlorophyll, Secchi depth may be inversely proportional to standing stock of phytoplankton (Nolten 1980), and hence an indirect indicator of of increased food availability across trophic levels. However, Secchi depth was also shown to be least during ebb tide in areas where terrestrial runoff is important.

It is not known how water clarity effects harbor porpoises' ability to detect prey. Sekiguchi (1987) noted an increase in sightings during ebb tide, when visibility is low, and a harbor porpoise in captivity was observed to use sonar scans regularly when investigating unfamiliar objects (pers. obs.). Both these facts support the idea that vision may not be crucial in finding prey.

The fact that Secchi depth by season showed no statistical difference, and that individual stations were consistently different from one another over all seasons, suggests that water clarity patterns may be affected by local 
conditions instead of seasonal ones. Significant differences between incoming and outgoing tides support this. Nolten (1980) showed that Secchi depth was indicative of both turbidity and chlorophyll level. Therefore, variation in water clarity reflected changes in both conditions, and the present study could not distinguish between the two. Appropriate measurement of chlorophyll content would thus have had to be carried out by direct sampling.

\section{Distribution}

Harbor porpoises were found in the warmest waters on the transect, possibly because of energetic effects, feeding, protection from predators, or depth. Yasui and Gaskin (1986) conjectured harbor porpoises may have a comparatively higher metabolic rate than other cetaceans due to their small size and occurrence in a cold environment. Although harbor porpoises may seek warmer areas of Monterey Bay to minimize thermal stress, they may not sustain as high an energetic deficit as was once thought (Worthy pers. comm.), casting doubt on this hypothesis.

Further question of migration for thermoregulation comes from Watts and Gaskin (1985), studying harbor porpoise movements in relation to water temperature. Temperatures in the Bay of Fundy are generally colder (by 7 or 8 ${ }^{\circ} \mathrm{C}$ ) than Monterey Bay, yet harbor porpoises were found to be more abundant in temperatures lower than average, and prey distribution was considered the best predictor of harbor porpoise abundance. Thus, temperature may only indirectly influence harbor porpoise distribution by dictating spatial patterns of prey abundance. 
Harbor porpoises have a catholic diet of pelagic and benthic fishes and cephalopods, but the major prey items in central California were northern anchovy (Engraulis mordax) and market squid (Loligo opalescens) (Jones 1981, Sekiguchi 1987). This study gathered no direct evidence of increased food abundance or availability coinciding with areas of high porpoise concentration (Fig. 7), but northern anchovy are commonly observed in temperatures of 12 to $20^{\circ} \mathrm{C}$ (PFMC 1978), and thus are expected to be found in the warmer transect waters.

Food availability also may influence temporal distribution of harbor porpoise. Market squid habitually spawn off Monterey, well outside the study area, mostly between April and June (McInnis 1976). While spawning, market squid form dense schools 30 to $40 \mathrm{~m}$ thick and 70 to $200 \mathrm{~m}$ in horizontal dimension, easily captured by fishing boats (Mais 1974). Thus, spawning market squid appear to be a predictable resource, and may attract harbor porpoises from other parts of the Bay between April and June.

Sightings of harbor porpoises along the transect remained low during the market squid spawning period. Large numbers of harbor porpoises also were gill-netted in south Monterey Bay, most with squid in their stomachs (Chapter 2). In August, after the normal decline of squid on the spawning grounds (McInnis 1976), harbor porpoise sightings on the transect showed a dramatic increase (Fig. 4). The California Department of Fish and Game instituted a moratorium on gill-netting in Monterey Bay on 1 August, 1989; consequently records of harbor porpoises from southern Monterey cease at this point. Despite lack of data from southern Monterey Bay, this area is the most logical origin of harbor porpoises in the north bay, as no other local area 
contains a similar abundance of animals (Szczepaniak and Webber 1985). The contention that Monterey Bay harbor porpoises migrate to take advantage of pulses of prey abundance is also supported by data from Smith and Gaskin (1973). They suggested harbor porpoises in the Bay of Fundy actively follow herring (Clupea harengus), cod (Gadus morhua), mackerel (Scomber scombrus), and other schooling fishes, during diurnal and seasonal migrations.

The increase in harbor porpoises sightings in north Monterey Bay after the squid spawning season might be explained by the phenomenon of internal tides: large-amplitude internal waves which cause semi-diurnal fluctuation in thermocline height. Shea and Broenkow (1982) showed that during high internal tide, the main thermocline rises above the canyon rim spreading deep, nutrient rich water onto the shelf. As internal tide ebbs, cells of canyon water are pinched off and pushed northward by the generally north ward currents in Monterey Bay (Broenkow and Smethie 1978). This internal tidally-induced density flow may account for up to $30 \%$ of daily primary productivity in north Monterey Bay during non-upwelling seasons (Shea and Broenkow 1982) .

Higher nutrient levels in north Monterey Bay could increase abundance in successive trophic levels. However, it is not known how long nutrients in canyon water wouid take to influence standing stock of phytoplankton, or where such influence would be manifest. Nutrient assimilation by phytoplankton in Monterey Bay is known to be fairly constant (7.4 $\pm 1.0 \mathrm{mg} \mathrm{C} \mathrm{mg} \mathrm{Chl} a^{-1} \mathrm{~h}^{-1} ;$ Malone 1971), but succession in phytoplankton communities is not straightforward (Smayada 1980). Further study is 
required to assess effects of nutrient enrichment and spatial patterns in Monterey Bay.

Although harbor porpoise sightings were not correlated with water clarity, a relationship may exist, which methods used in this study could not assess. Secchi depths at ebb versus flow tide indicated that water clarity is strongly affected by tidal state, at least in parts of the study area. Since tidal height is a function of time, which in this study was bound distance, effects of tide could not be distinguished from those of location.

Taylor and Dawson (1984) and Sekiguchi (1987) did, however, observe diurnal peaks in harbor porpoise abundance corresponding to high tide. In addition, Watts and Gaskin (1985) found that harbor porpoises preferred murky water, probably due to higher prey distribution in these areas. It is not known if a relationship exists between water clarity and prey distribution in Monterey Bay, but further study may elucidate this.

Watts and Gaskin (1985) also found that harbor porpoises preferred comparatively deeper water, which was not the case in this study. It is possible that the distribution of harbor porpoise predators: great white sharks (Carcharodon carcharias; Arnold 1972), and killer whales (Orcinus orca; Stroud and Roffe 1979, Heimiich-Boran 1988) limit harbor porpoise distribution to shallow waters. Although harbor porpoise predators have been sighted infrequently in Monterey Bay, observations of killer whales have been made over deep canyon waters and near the Monterey Peninsula, areas of low harbor porpoise abundance (Black unpubl. data). Great white shark sightings are primarily to the north at Año Nuevo, which harbors large populations of elephant seals (Mirounga angustirostris) and California sea 
lions (Zalophus californianus). Although harbor porpoise distribution in Monterey Bay cannot be linked directly to predator distribution, location of harbor porpoises in Monterey Bay probably precludes frequent interactions.

Differences between Bay of Fundy and Monterey Bay, in depth in which harbor porpoises are found, may be due to movements of major prey items. In the Bay of Fundy, harbor porpoises take numerous herring, a midwater species (Watts and Gaskin 1985). In Monterey Bay, however, the most commonly consumed fish is the northern anchovy which commonly school in shallower water during daylight hours (Mais, 1974). Consequently, any difference in harbor porpoise depth associations from those of the Bay of Fundy may be due to differences in fish schooling in the two areas.

\section{Behavior}

Although harbor porpoise behavior is difficult to observe and interpret, even inferential knowledge is valuable, for understanding diurnal and seasonal movements and enhancing predictive ability. For example, milling may be indicative of feeding activity (Sekiguchi 1987). Watson and Gaskin (1983) also attributed patterns of milling-like behaviors to foraging. Harbor porpoises were clearly observed in interactions with fish schools only while milling. On three occasions, harbor porpoises were observed jumping vertically through an obvious surface boil of bait fish. On one of these occasions, approximately 50 western Grebes (Aechmophorus occidentalis) were observed actively diving, and presumed feeding. 
This study concurred with findings of Silber and Smultea (in press) that milling activity occurred more often in surface slicks than in non-slick areas. Slicks concentrate prey (Kingsford and Choat 1986), creating areas of high food concentration and possibly predictability. Silber and Smultea (in press) did not show significant behavioral differences in non-slicked areas, as did this study. They collected their data from cliff-top, and therefore did not create a disturbance factor as might have happened in boat observations. Obvious boat reactions, however, were removed from the analysis at the outset and this study found no significant differences in behavioral observations from cliff-top and boat. Differences between this study and Silber and Smultea (in press) may have resulted from different criteria used in assigning behavioral state or a behavioral shift of study animals.

Whatever the causes of differences, the basic trend is the same: harbor porpoises behave differently in surface slicks.

Juvenile harbor porpoises were probably young of the year, being an estimated $1 \mathrm{~m}$ in length (approximately $60 \%$ of adult length), and behaving differently. Frequently, young harbor porpoises would approach the boat while swimming just under the water's surface, with dorsal fin exposed. They would often swim under the boat or through the stern wake. On several occasions, young harbor porpoises were observed following the boat. These behaviors contrasted with adult harbor porpoises which were never seen approaching the boat, and often observed swimming away from it.

Circumstantial evidence gathered during this study suggest that aerial behaviors of harbor porpoises may be related to courtship and mating. First, juveniles did not engage in aerial behaviors during this study, though adults 
and juveniles performed other behaviors in proportions similar to one another. Aerial behaviors were also observed most frequently near the estimated peak of the breeding season, based on time of parturition. Although Sekiguchi (1987) suggested that jumping patterns were linked to "probable feeding," 77\% of her observed conspicuous behaviors occurred between 11 June and 29 October (98\% between 11 June and 19 November), substantially overlapping the breeding season of harbor porpoise.

Aerial behaviors of wild dusky dolphins (Lagenorhynchus obscurus), were placed into three categories: "noisy leaps," in preparation for deep dives, occurring most before feeding, "plain noisy leaps," thought to attract conspecifics during feeding, and "acrobatic noisy leaps," occurring after feeding, and attributed to social-sexual behavior (Würsig and Würsig 1980). Leaping was also linked to social interactions in bottlenose dolphins (Würsig and Würsig, 1979). Aerial behaviors of harbor porpoises in Monterey Bay may be analogous to the acrobatic noisy leaps exhibited by dusky dolphins. During times of peak abundance of harbor porpoise, leaps rotating on the longitudinal axis were observed, and flips, both anterior and posterior, were common.

A number of biases may have been associated with this study, especially with regards to sampling. Harbor porpoises may have been easier to see in slicks, or when pod sizes were larger. Pods may have been more difficult to see when seas were rougher, even between Beaufort states of 1 and 2. Since many observers only were available one or a few occassions there may have been high variability in observation quality. 
Concurrent observation from cliff-top and boat attempted to address some of these possible biases, and it is hoped that overall differences in harbor porpoise abundance and distribution outweighed noise in data collection.

In addition, harbor porpoises could have moved from $10 \mathrm{~m}$ to $20 \mathrm{~m}$ before the boat had passed, so resighting may have been a problem. Because the southern portion of the Bay was always sampled in the morning due to constraints of wind, biases would have occurred in behavior or distribution patterns had a diurnal component. 


\section{CHAPTER 2}

A Comparison of Methods used in Analysis of Cetacean Stomachs.

\section{INTRODUCTION}

A number of calculations have been developed for evaluating the importance of prey items. The most widely used is the index of relative importance (IRI), which was developed by Pinkas et al. (1971) for use with scombrid fishes. It takes into account prey numbers, size, and abundance, which are doubtless important, but may not represent the entire view. As an example, northern anchovies (Engraulis mordax) and market squid (Loligo opalescens) are similar in mass, both quite abundant, and likely caught in large numbers. Anchovies, however, contain more calories than squid, and may in fact be a more important dietary item during certain times of year (Table 1).

Caloric estimates of prey importance, although desirable, were considered logistically unfeasible (e.g., Pinkas et al. 1971, Perrin et al. 1973). Estimates of caloric importance are labor intensive, but have the decided value of being in units common to all species. Because a considerable amount of background information was gathered in recent years, caloric estimations are now more straightforward. Energetic calculations were facilitated by Sidwell (1981), who reviewed the chemical composition of a great number of marine vertebrates and cephalopods. Comparisons of hardpart size to mass (Wolff 1982 and Harvey 1988) allow estimations of size of individual prey items. This study compares prey importance using IRI and caloric value. 


\section{MATERIALS AND METHODS}

Stomach contents were collected from 19 stranded harbor porpoises in Monterey County between September 1987 and July 1990 (Table 2). Contents were strained through $0.1 \mathrm{~mm}$ and $0.01 \mathrm{~mm}$ sieves and sorted under a dissecting microscope. Beaks and otoliths were identified to the lowest taxon possible. Unidentified otoliths and fragments were not used in the analysis. Otolith length to weight calculations were taken from Harvey (1988), and beak rostral length to weight calculations from Wolff (1982; Fig. 11). Caloric information was taken from Sidwell (1981), who calculated energy value each species by the formula: Estimated energy value $=($ protein * 4$)+($ fat $* 9)+$ (carbohydrate *4). Data were from wet samples.

When caloric information was unavailable, a value was substituted from the closest related species available. Bearded cuskeel (Ophiodon barbatum) was used for spotted cuskeel, the damselfish Chromis chromis, for embiotocids, the smelt Osmerus dentex for night smelt, and yellow croaker (Umbrina steindacneri) for white croaker.

Stomach contents were analyzed using an index of relative importance (IRI), of Pinkas et al. (1971), given as:

$$
\mathrm{IRI}=(\% \text { NUMBER }+\% \text { MASS }) \times \% \text { FREQ } . \text { OF OCCURRENCE } .
$$

Although the original equation employs volume, mass is acceptable in its stead (Hyslop 1980). Percent mass was back-calculated based on hard part size. 
Percent caloric contribution (\%CC), was calculated for each prey species (i):

$$
\% C C=\left[\frac{\mathrm{PM}_{i}^{*} \mathrm{PC}_{i} * \frac{N T_{i}}{\mathrm{~S}}}{\sum_{\mathrm{i}=1}^{\mathrm{a}} \frac{\left(\mathrm{PM}_{\mathrm{i}} * \mathrm{PC}_{\mathrm{i}} * N \mathrm{NT}_{i}\right)}{\mathrm{S}}}\right] * 100
$$

where

PM = Ave. mass ( $g$ ) of an average prey species $\mathrm{i}$.

$P C=$ Kilocalories per gram of prey species $i$.

NT = Total number of species I for all stomachs.

$\mathrm{S} \quad=$ Total number of stomachs.

a $\quad=$ Total number of identifiable species.

It was assumed that all otoliths retrieved from stomachs represented fishes caught that day, because pepsin may degrade otoliths in 4.5 hours (Le Brasseur and Stephans (1965). Because cephalopod beaks remain in cetacean stomachs for an unknown period, possibly as long as four days before physical degradation (Harvey, pers. comm.), it was assumed that one quarter were consumed 24 hours before capture. 


\section{RESULTS}

Harbor porpoises consumed a variety of prey, including market squid, northern anchovy, and other open-water and shallow benthic species (Table 1). Percent caloric contribution indicated market squid were more important than other prey items, northern anchovy second (Fig. 12). IRI calculations were spread less evenly throughout prey types (Fig. 12, Table 3). Market squid was far more important than other species, and northern anchovy was the only other species represented substantially. Night smelt were ranked 4th using \%CC and 8th by IRI. All other species were in the same order by both methods. 


\section{DISCUSSION}

The least abundant species were better represented using \%CC than IRI. IRI is affected greatly percent frequency of occurrence, which was 0.01 for these species. More of the difference between the two indices may be explained by differences in caloric value.

Several possible biases may have effected the results of this study. Prey mass may have been underestimated, due to otolith digestion. In addition, otolith types that degrade quickly may have been underestimated, compared to those that degrade more slowly. Back-calculating mass and calories does not enable use of unidentified hard-parts, and replacement of prey-species caloric value with similar species may have misrepresented those found in harbor porpoise stomachs. This study also assumed that harbor porpoises assimilate calories from all prey species at an equal rate, which may not be true. It is assumed that none of these possible biases obscured trends of this analysis; however further study is required to address these factors in detail.

Harbor porpoises are catholic feeders, consuming bottom dwelling fishes, a variety of small mid- water and epipelagic fishes and cephalopods. In Monterey Bay, the primary food items of harbor porpoise are market squid (Loligo opalescens), and northern anchovy (Engraulis mordax) (Jones 1981, Sekiguchi 1987), though they also take a variety of prey such as surf perches (Embiotocidae), rock fishes (Sebastes spp.), Pacific herring (Clupea harengus pallasi), white croaker (Genyonomus lineatus), Pacific Hake (Merluccius productus), plainfin midshipman (Porichthys notatus), and other species. On two occasions, harbor porpoises were also observed pursuing small $(\sim 1 \mathrm{~m})$ 
thresher sharks (Alopias spp., pers. obs.). Although interpretation of these events is difficult, the fact that Orr (1937) discovered a 56-cm grey smoothhound shark (Mustelus californicus) in the stomach and esophagus of a $101-\mathrm{cm}$ harbor porpoise indicates that some elasmobranchs may be sought as prey. Harbor porpoises also consume other fishes large enough to cause strangulation (Orr 1937, Hult et al. 1980, Duffield, pers. comm.).

Harbor porpoises feed primarily on an assemblage of prey items endemic to the epipelagic zone (Horn 1980). The most common prey species of this assemblage are market squid and northern anchovy, which Morejohn et al. (1978) showed combine with euphausids and rockfishes to comprise the bulk of prey for Monterey Bay's large vertebrates.

The other common prey species in the diet of the harbor porpoise are either those associated with the epipelagic assemblage, or shallow benthic fishes, indicating harbor porpoises feed in relatively shallow waters, and may do so opportunistically. Harbor porpoises studied in other areas also were considered opportunistic feeders. Smith and Gaskin (1973) reported harbor porpoises seemed to follow schools of prey species diurnally and seasonally, and Rae (1965) suggested harbor porpoises fed on fishes in the proportions in which they were available.

Percent CC seems to be a more appropriate measure of the relative importance of harbor porpoise prey than IRI. However, if IRI is used it must be done correctly. Sekiguchi (1987) employed a "modified IRI," to analyze nine harbor porpoise stomachs, which omitted percent mass or volume. This defeated the purpose of the index, as Hyslop (1980) stated that using purely numerical methods tends to overestimate the importance of small prey items 
taken in quantity. The difficulty of calculating mass measurements of prey items in cetacean stomachs lies in the fact that much of the material found is digested beyond recognition. Therefore, masses in this study were backcalculated based on hard-part size. It is a labor-intensive process, as hard-parts must be measured individually, and required the application of allometric formulae. However, these results account for a larger percentage of prey items, because hard-parts are more recognizable to species than other digested material. 


\section{GENERAL CONCLUSIONS}

\section{Distribution}

Harbor porpoises exhibited seasonal distribution patterns which, if consistent, would greatly aid in predicting their habits in Monterey Bay. Harbor porpoise abundance on the transect changed seasonally, being greatest during the oceanic period (August through October 1989). During this time, harbor porpoises were associated with warm shallow waters. This could be due to a combination of factors, including predator avoidance, thermoregulation, or a preference for calmer waters. This association, and seasonal changes in distribution, probably reflects changes in abundance of northern anchovy and market squid.

\section{Behavior}

Aerial behaviors increased dramatically during the oceanic period, concurrent with both the greatest number of sightings, and breeding season, possibly indicating a link to social activity. Post-weaning juveniles were not observed engaging in aerial behaviors, and congregated apart from adults primarily in the northern portion Monterey Bay. Because reproductive potential of harbor porpoises is low, areas of high juvenile concentration should be important in habitat management.

Within internal surface slicks, harbor porpoises milled more often than travelled, whereas outside slicks harbor porpoises were observed traveling more than milling. This pattern may indicate harbor porpoises feeding in areas of high food availability within surface slicks. More research 
is required to assess the importance of internal waves to harbor porpoises in Monterey Bay.

\section{Food Habits}

The importance of market squid and northern anchovy in the harbor porpoise diet was demonstrated by both percent caloric contribution and IRI. The former, however, is a more sensitive measure of stomach contents as evidenced by better representation of seldom consumed, but more nutritious species. This is especially true for predators which feed on species with a wide range of nutritional value. 


\section{REFERENCES}

Au, D. and W. F. Perryman. 1985. Dolphin habits in the eastern tropical Pacific. Fish. Bull. 83(4):623-643.

Andersen, S. 1973. The taming and training of the harbor porpoise Phocoena phocoena. Cetology. 24:1-9.

and A. Dziedzic. 1964. Behaviour pattens of captive harbour porpoise Phocoena phocoena (L.). Bull. Inst. Oceanogr. Monaco. 63(1316):1-20.

Arnold, P. W. 1972. Predation on harbour porpoise, Phocoena phocoena by a white shark Carcharodon carcharias. J. Fish. Res. Board Can. 29:1213-4.

Barlow, J. 1987. An assessment of the status of harbor porpoise populations in Central California. NMFS Southwest Fisheries Center Admin. Rep. LJ-87-06.

Bolin, R. L. and D. Abbott. 1963. Studies on the marine climate and phytoplankton of the central coastal area of California, 1954-1960. CalCOFI Rep. 21: 23-45.

Breaker, L. C. and W. W. Bioenkow. 1989. The circulation of Monterey Bay and related processes. Moss Landing Marine Laboratories Technical Publication 89-1. 91 pp.

Briggs, R. and E. W. Chu. 1987. Trophic relationships and food requirements of California seabirds: updating models of trophic impact. In J. P. Croxall (edl) Seabird feeding Ecology and Role in Marine Ecosystems. Cambridge Univ. Press. Cambridge.

Broenkow, W. W. and W. Smethie. 1978. Surface circulation and replacement of water in Monterey Bay. Estuar. Coast. Mar. Sci. 6:583603.

Chapman, D., L. Eberhardt and J. Gilbert. (1977). A review of marine mammal census methods. Marine Mammal Commission Report MMC-74/01. 
Clarke, M. R. 1986. A Handbook for the Identification of Cephalopod Beaks. Clarendon Press, Oxford.

Ewing, G. 1950. Slicks, surface films and internal waves. J. Mar. Res. 9(3):161-187.

Fisher, H. D., and R. Harrison. 1970. Reproduction in the common porpoise (Phocoena phocoena) of the North Atlantic. J. Zool. 161:471-486.

Gaskin, D. E. 1968. Distribution of Delphinidae (Cetacea) in relation to sea surface temperatures off eastern and southern New Zealand. J. Mar. Freshwat. Res. 2:527-534.

, P. Arnold and B. A. Blair. 1974. Phocoena phocoena. Mammalian Species. 42:1-8.

- and B. A. Blair. 1977. Age determination of harbor porpoise, Phocoena phocoena (L.) in the western North Atlantic. Can J. Zool. 55(1):18-30.

, G. J. D. Smith, A. P. Watson, W. Y. Yasui and D. B. Yurick. 1984. Reproduction in the porpoises (Phocoenidae): implications for management. In Reproduction in Whales, Dolphins and Porpoises, W. F. Perrin, R. L. Brownell Jr. and D. P. DeMaster (eds.) Rep. Int. Whal. Commn. Sp. Issue 6. 135-148.

Harvey, J.T. 1988. population dynamics, annual food consumption, movements and dive behaviors of harbor seals, Phoca vitulina richardsi, in Oregon. PhD thesis, Oregon State University. 177pp.

Heimlich-Boran, J. R. 1988. Behavioral ecology of killer whales (Orcinus orca) in the Pacific Northwest. Can. J. Zool. 66:565-578.

Hui, C. 1979. Undersea topography and distribution of dolphins of the genus Delphinus in the Southern California Bight. J. Mamm. 69(3):521-527.

1985. Undersea topography and the comparative distributions of two pelagic cetaceans. Fish. Bull. 83(3):472-475.

Horn, M. 1980. Diversity and ecological roles of noncommercial fishes in California marine habitats. CalCOFI Rep., 21:37-47. 
Hult, R. W., S. Dupey and R. Badley. 1980. Mortalities associated with prey ingestion by small cetaceans. Cetology. 0(36):1-2.

Hyslop, E. 1980. Stomach contents analysis - a review of methods and their application. J. Fish. Biol. 17:411-429.

Jefferson, T. A. 1987. A study of the behavior of Dall's porpoise Phocoenoides dalli) in the Johnstone Strait, British Columbia. Can J. Zool. 65:736-744.

Jones, R. E. 1981. Food habits of smaller marine mammals from Northern California. Proc. Ca. Acad. Sci. 42(16):433-509.

Kanwisher J., and G Sundnes. 1965. The physiology of a small cetacean. Hvalradets Skr. 48:45-53.

Kastelein, R. A. and R. van Battum. 1990. The relationship between body weight and morphological measurements in harbour porpoises (Phocoena phocoena) from the North Sea. Aquat. Mamm. 16.2:48-52.

Kinze, C. C. 1985. Intraspecific variation in Baltic and North Sea harbor porpoises (Phocoena phocoena (L., 1758)). Videnk. Meddr dansk Foren. 146:63-74.

Kingsford, M. J. and J. Choat. 1986. Influence of surface slicks on the distribution and onshore movements of small fish. Mar. Biol. 91:161171.

Kukas, S. T. 1986. Species profiles: Life histories and environmental requirements of coastal fishes and invertebrates (Pacific Southwest)-northern anchovy. U.S. Fish Wildl. Serv. Biol. Rep. 82(11.50). U.S. Army Corps of Engineers, TR EL-82-4. 12pp.

Kukowski, G. E. 1972. Benthic fishes associations from two depths in Monterey Bay, California. MA thesis, Moss Landing Marine Laboratories, Moss Landing, CA. 42pp.

Lasley, S. R. 1977. Hydrographic changes in Monterey Bay surface waters in relation to nearshore circulation. MA thesis, Moss Landing Marine Laboratories, Moss Landing, CA. 75pp. 
Le Brasseur, $\mathrm{R}$. and K. Stephans. 1965. Relative rates of degradation of some organisms consumed by marine salmon. J. Fish. Res. Board of Canada. 22(6): 1563-1564.

Ljungblad, D. K., B Würsig, S. L. Swartz and J. M. Keene. 1988. Observations on the behavioral responses of bowhead whales (Balaena mysticetus) to active geophysical vessels in the Alaskan Beaufort Sea. Arctic. 41(30):183-194.

Mais, K. F. 1974. Pelagic fish surveys in the California current. Cal. Dept. Fish and Game, Fish Bull. 162:1-79.

Malone, T. C. 1971. The relative importance of nanoplankton and netplankton as primary producers in the California Current system. Fish. Bull. 69(4):799-820

McInnis, R. R. 1976. Correlations between the squid fishery and environmental factors in Monterey Bay, California. MA thesis, Moss Landing Marine Laboratories., Moss Landing, CA 31pp.

Morejohn, G. V., J. Harvey and L. Krasnow. 1978. The importance of Loligo opalescens in the food web of marine vertebrates in Monterey Bay, California. In Recksiiek, C. and H. Frey (eds.)Biological, Oceanographic, and Acoustic aspects of the Market Squid, Loligo opalescens. Berry. Cal. Dept. Fish and Game fish Bull. 196. 185pp.

Nolten, J. W. 1980. In situ optical methods for chlorophyll estimation in the sea. MS thesis, Moss Landing Marine Laboratories, Moss Landing, CA. 43pp.

Orr, R. 1937. A porpoise chokes on a shark. J. Mamm. 18(3):370.

Pacific Fishery Management Council. 1978. Northern anchovy fishery management plan. Federal Register 43(141), Book 2:31655-31879.

Perrin, W., R. Warner, C. Fiscus and D. Holts. 1973. Stomach Contents of Porpoise Stenella spp. and Yellowfin Tuna, Thunnus albacares, in mixed species aggregations. Fish. Bull. 71(4):1077-1092.

Pinkas, L., M. Oliphant and I. Iverson. 1971. Food habits of albacore, bluefin tuna, and bonito in California waters. Cal. Dept. Fish and Game Fish Bull. 152. 105pp. 
Rae, B. 1965. The food of the common porpoise (Phocoena phocoena). Proc. Zool. Soc. Lond. 146:114-122.

Read, A. J. 1990a. Reproductive seasonality in harbour porpoises, Phocoena phocoena, from the Bay of Fundy. Can. J. Zool. 68:284-288.

1990b. Age at sexual maturity and pregnancy of harbor porpoises Phocoena phocoena from the Bay of Fundy. Can. J. Fish Aquat. Sci. 47:561-565.

- and D. Gaskin. 1985. Radio tracking the movements and activities of harbor porpoises, Phocoena phocoena (L.), in the Bay of Fundy using radiotelemetry. Can J. Zool. 53(10):1466-1471.

Schrader, G. C. 1980 . Seasonal cycles of phytoplankton in relation to the hydrography of Monterey Bay. MS Thesis, Moss Landing Marine Laboratories, Moss Landing, CA. 104pp.

Sekiguchi, K. 1987. Occurrence and behavior of harbor porpoises (Phocoena phocoena ) at Pajaro Dunes, Monterey Bay, California. MS thesis, Moss Landing Marine Laboratories. 49pp.

Shanks, A.L. and W. Wright. 1987. Internal-wave-mediated shoreward transport of cyprids, magalopae, and gammarids and correlated longshore differences in settling rate of intertidal barnacles. J. Exp. Mar. Biol. 114:1-13.

Shea, R. E. and W. W. Broenkow. 1982. The role of internal tides in the nutrient enrichment of Monterey Bay, California. Est. Coast. Shelf Sci. 15:57-66.

Sidwell, V.D. 1981. Chemical and nutritional composition of finfishes, whales, crustaceans, mollusks, and their products. NOAA Technical Memorandum NMFS F/SEC-11. 432pp.

Silber G. K. and M. Smultea. In press. Harbor porpoises utilize tidallyinduced internal waves. Proc. So. Cal. Acad. Sci.

Smayada, T. J. 1980. Phytoplankton species succession. In I. Morris (ed.) The Physiological Ecology of Phytoplankton. University of California Press, Berkeley. 
Smith, G. and D. Gaskin. 1973. The diet of harbor porpoises (Phocoena phocoena (L.)) in coastal waters of Eastern Canada, with special reference to the Bay of Fundy. Can J. Zool. 52:777-782.

-1985. An environmental index for habitat utilization by female harbour porpoises with calves near Deer Island, Bay of Fundy. Ophelia. 22(1):1-13.

Stroud. R. K. and T. Roffe. 1979. Causes of death in marine mammals stranded along the Oregon coast. J. Wildl. Diseases. 51:91-97.

Szczepaniak, I. D. and M. A. Webber. 1985. Status of the harbor porpoise (Phocoena phocoena) in the eastern North Pacific, with an emphasis on California. Report to the Center for Environmental Education. Washington, D. C. 52 pp. (Unpubl.).

Taylor, B. L. and P. K. Dawson. 1984. Seasonal changes in density and behavior of harbor porpoise (Phocoena phocoena) affecting censusing methodology in Glacier Bay National Park, Alaska. Rep. Int. Whal. Commn. 34:479-483.

Watson, A. and D. Gaskin. 1983. Observations on the ventilation cycle of the harbor porpoise Phocoena phocoena (L.) in coastal waters of the Bay of Fundy. Can. J. Zool. 61(1):126-132.

Watts, P. and D. Gaskin. 1985. Habitat index analysis of the harbour porpoise (Phocoena phocoena) in the southern coastal Bay of Fundy, Canada. J. Mamm. 66(4):733-744.

Wilke, F. and K. Kenyon. 1952. Notes on the food of fur seal, sea-lion and harbor porpoise. J. Wildl. Mgmt. 16:396-397.

Wolff, Gary. 1982. A Beak Key for Eight Eastern Tropical Pacific Cephalopod Species With Relationships Between their Beak Dimensions and Size. Fish. Bull. 80(2):357-370.

Würsig, B.G. 1984. Aspects of the natural history of bottlenose and dusky dolphins. Nat. Geog. Res. Rep. 1975:759-769.

Würsig, B. G. and M. Würsig. 1979. Behavior and ecology of the bottlenose dolphin Tursiops truncatus, in the South Atlantic. Fish Bull. 77(2):339-412. 
Würsig, B. G. and M. Würsig. 1980. Behavior and ecology of the dusky dolphin, Lagenorhynchus obscurus, in the South Atlantic. Fish Bull. 77(4):871-890.

Yasui, W. Y. and D. Gaskin. 1986. Energy budget of a small cetacean, the harbour porpoise, Phocoena phocoena (L.). Ophelia. 25(3):183-197.

Yurick, D. B. and D. E. Gaskin. 1987. Morphometric and meristic comparisons of skulls of harbour porpoise Phocoena phocoena (L.) from the north Atlantic and north Pacific. Ophelia 27(1): 53-57. 


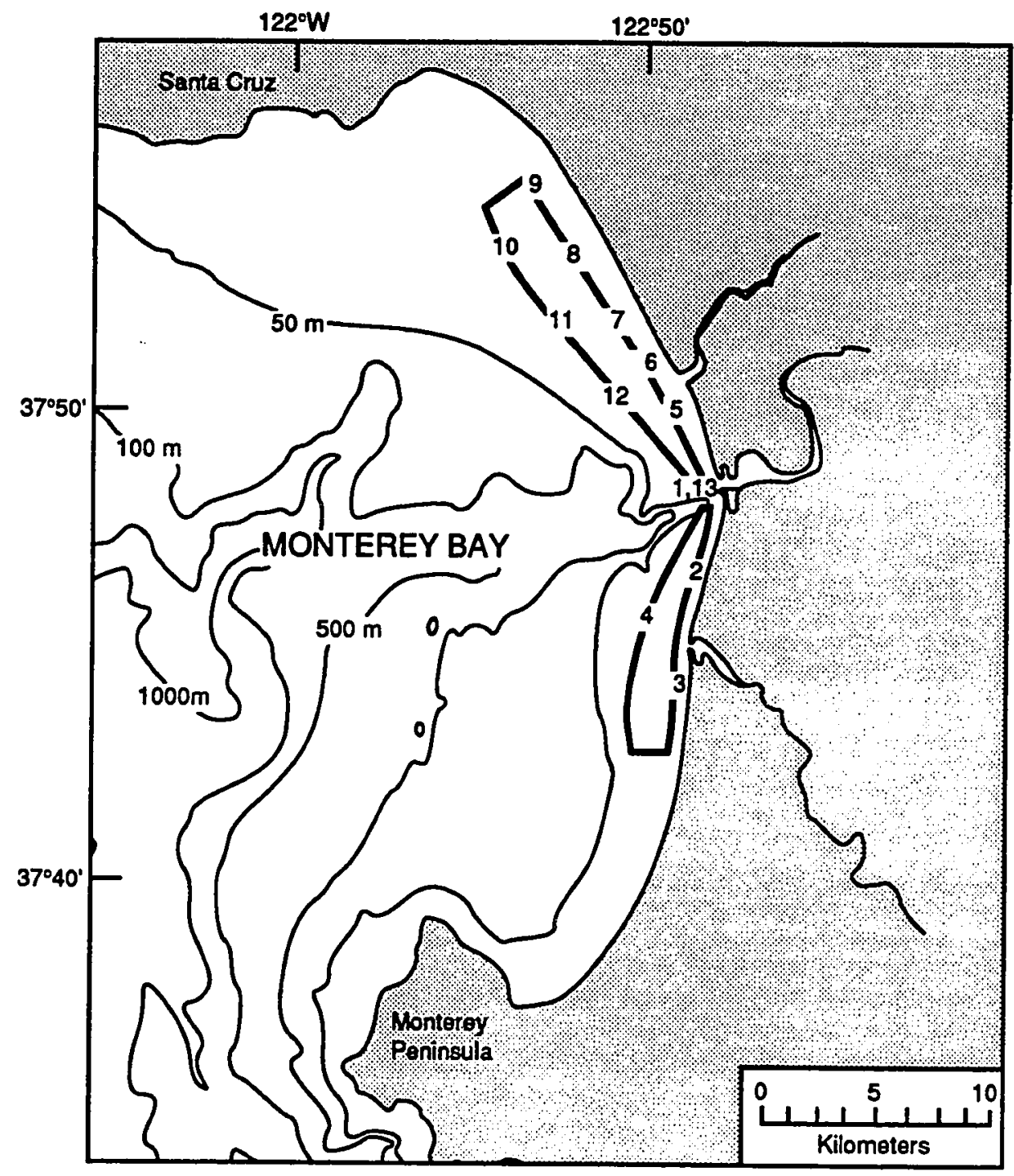

Fig. 1. Measurements of temperature and Secchi depth were taken at thirteen stations along the transect. 


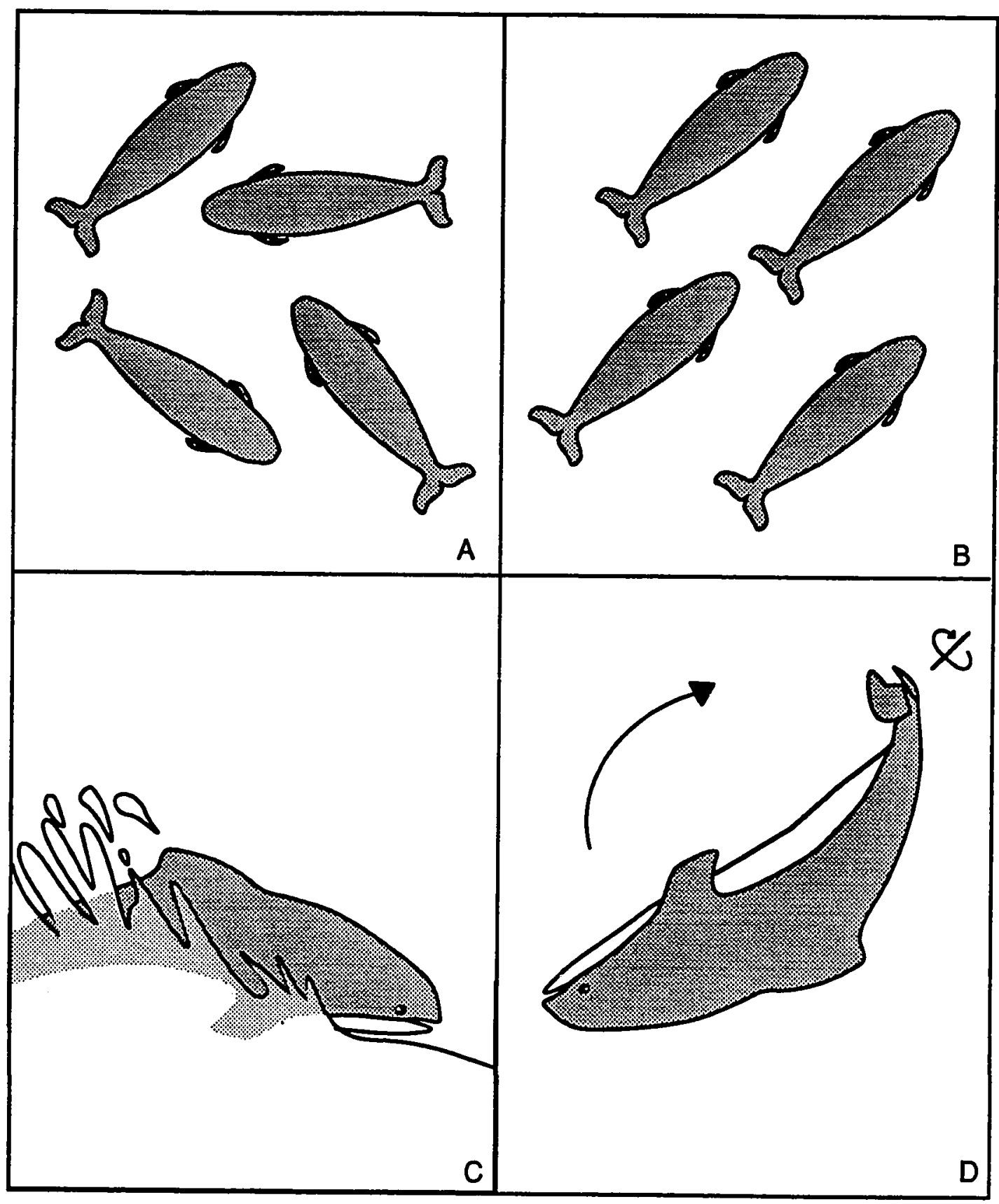

Fig. 2. An assignment of milling (A) was given if a total of of three surfacings were observed with different orientations to one another, and traveling (B) assigned if three surfacings were in the same orientation. Observations of pop splashing $(C)$ were used as one indicator of boat disturbance. Aerial behaviors (D) consisting of rotation on the longitudinal axis were observed, and anterior and posterior flips were common. 


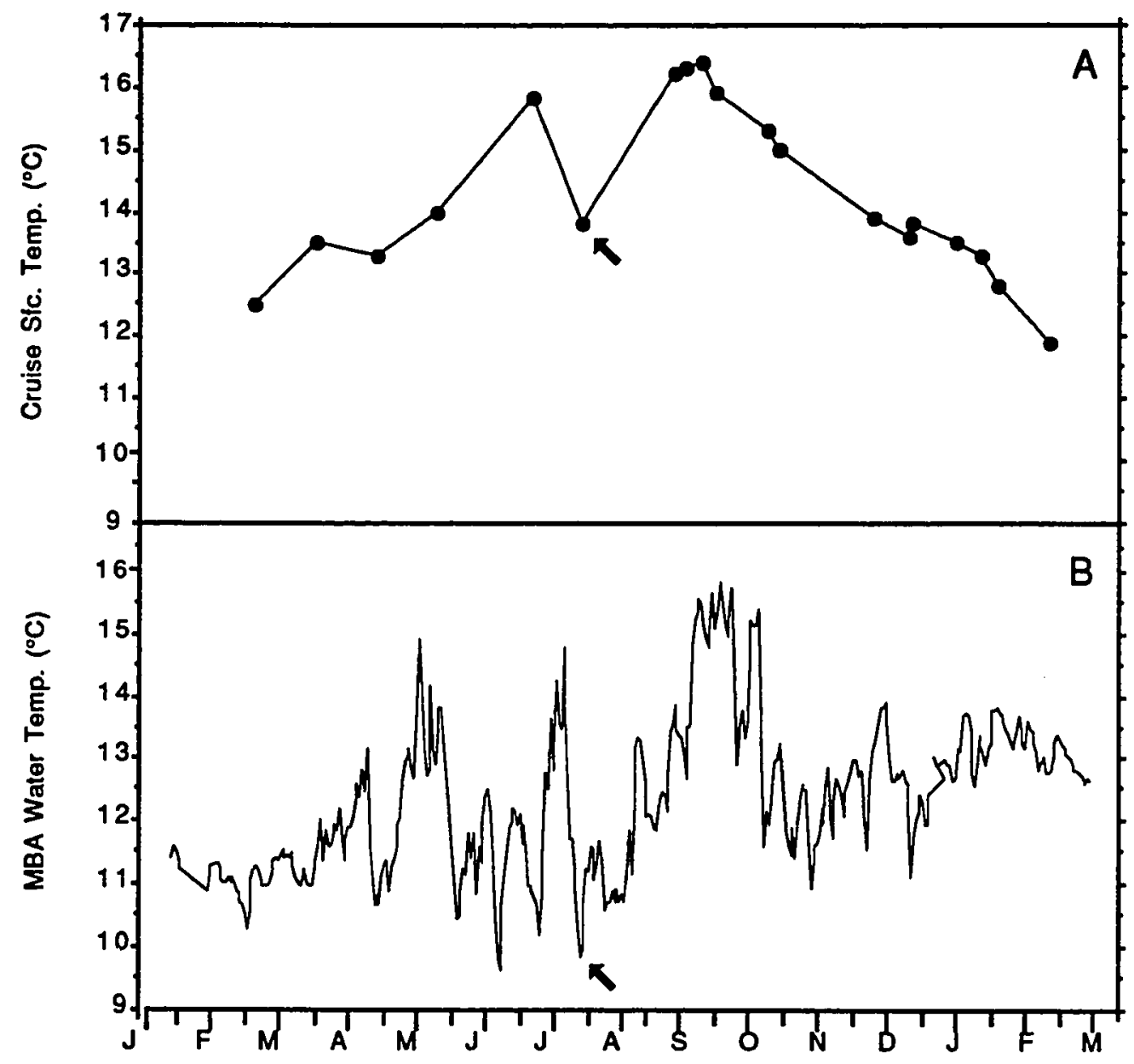

Fig. 3. The dramatic drop in temperature on 11 July 1989 (A, designated by arrow) is supported by data from the Monterey Bay Aquarium (MBA) at $7 \mathrm{~m}$ below MLLW (B), which shows a similar temperature decrease for that day (also designated by an arrow). 


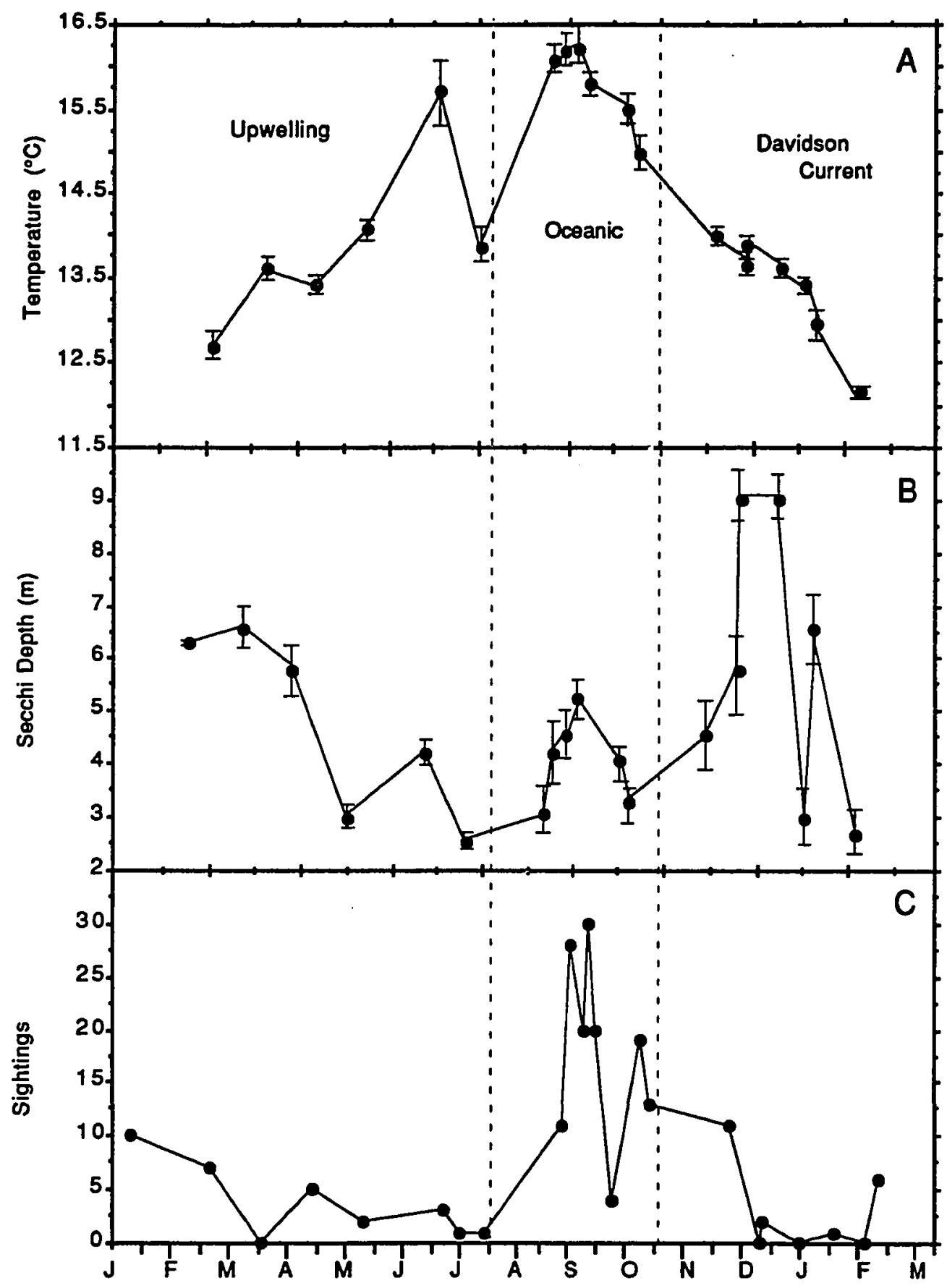

Fig. 4. Comparison of average temperature per cruise (A), average secchi depth per cruise (B) and number of sightings per hour per cruise $(C)$, over three oceanographic periods. Bars reflect one Standard Error. 


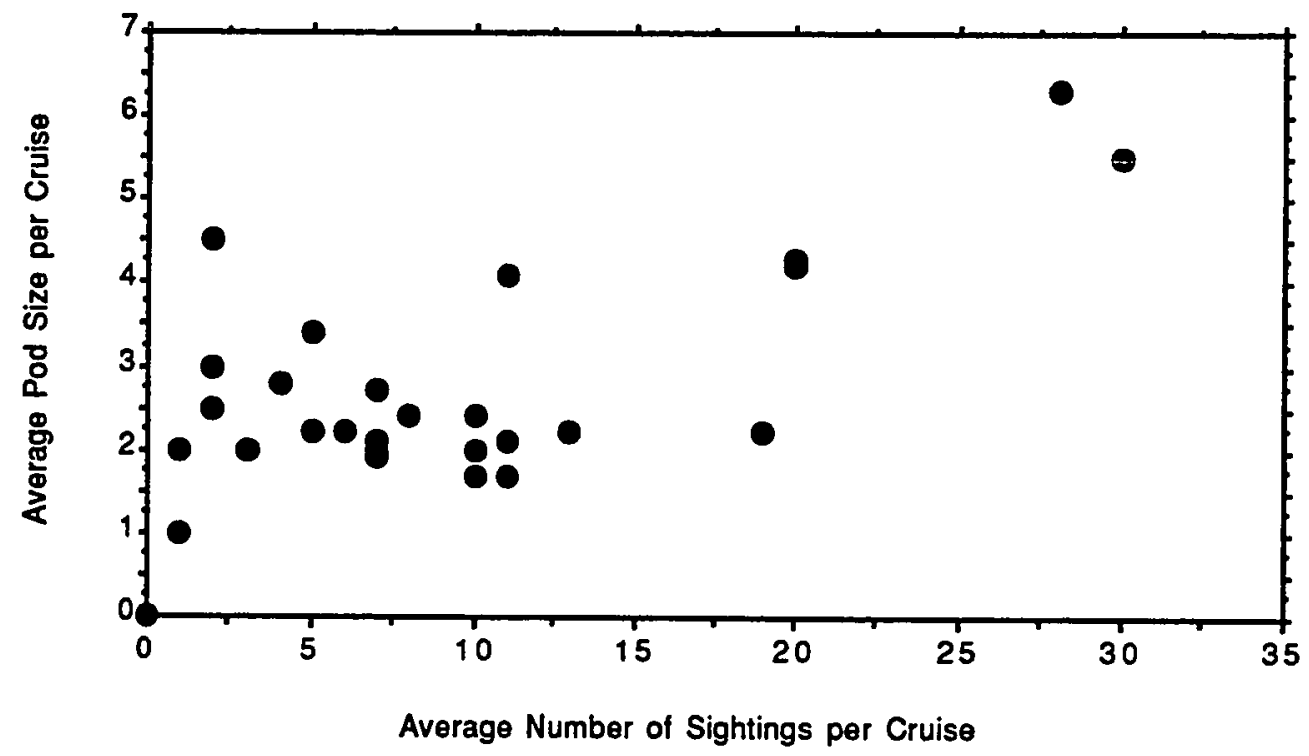

Fig. 5. Average pod size per cruise and number of pods per cruise were significantly correlated ( $r s=0.610, n=33, P<0.05$ ). 


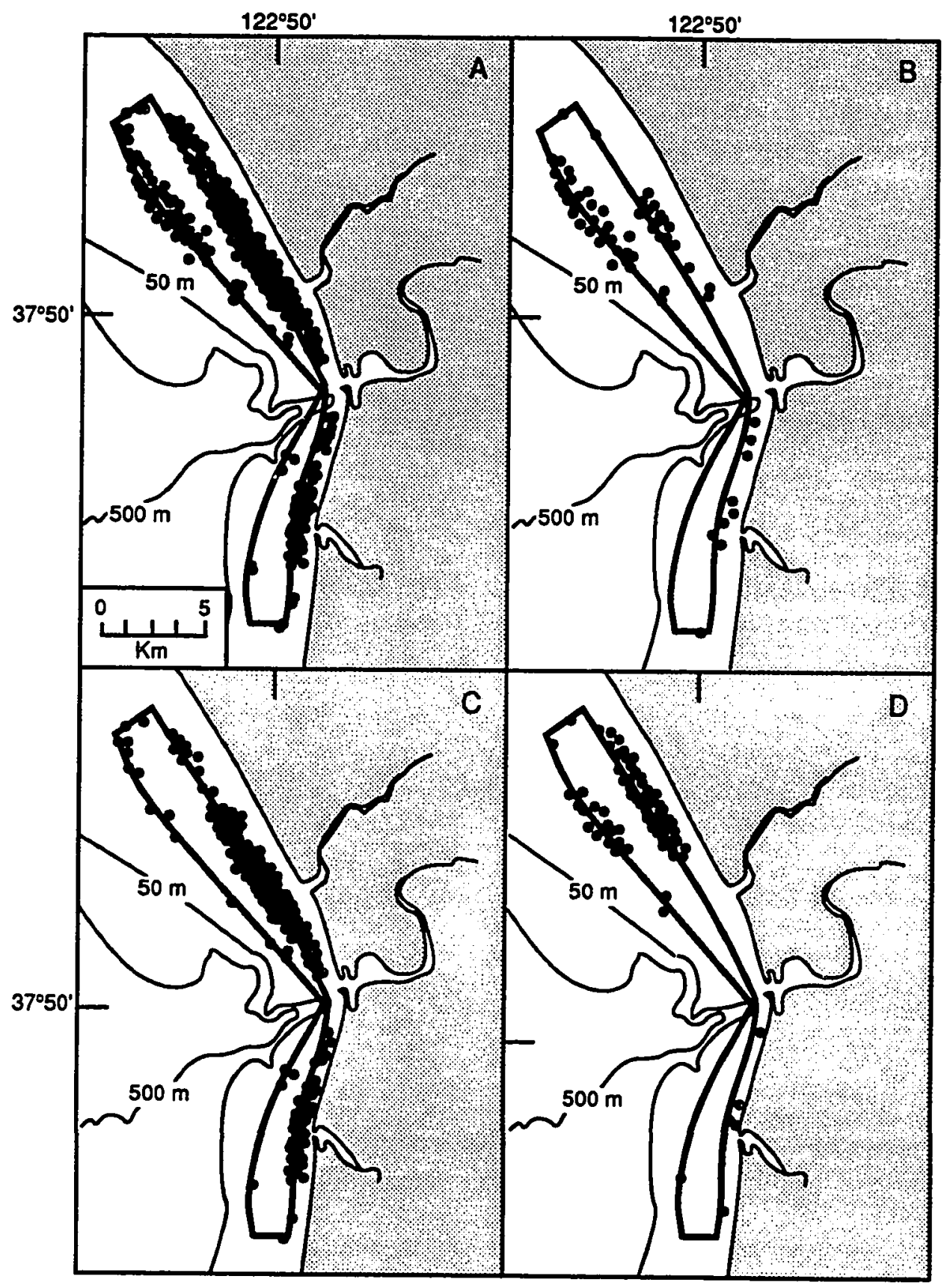

Fig. 6. Sightings of harbor porpoises over all periods (A), during the Upwelling period Jan. 1989 through Jul. 1989 (B). the Oceanic period Aug. 1989 through Oct. 1989 (C), and the Davidson Current period Nov. 1989 through Feb. 1990(D). 


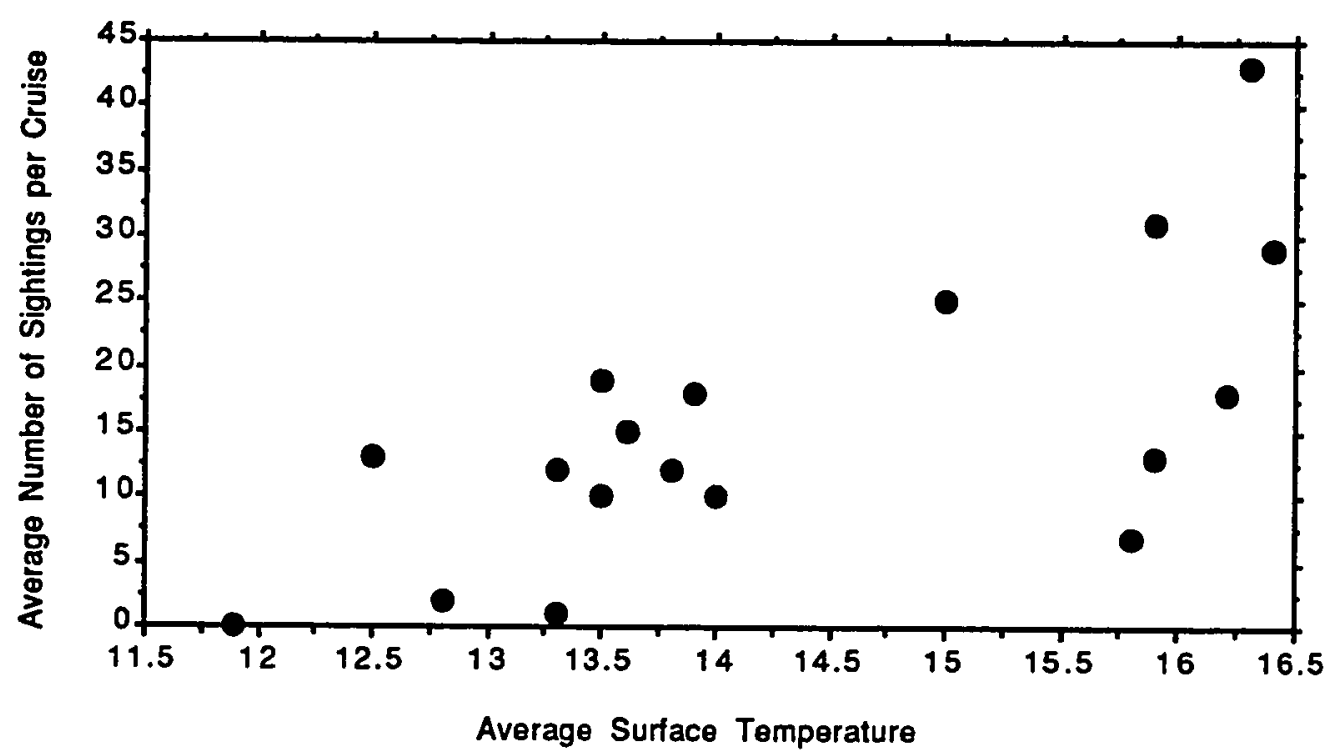

Fig. 7. Average number of sightings per cruise and average surface tepmerature per cruise were significanlty correlated ( $r s=0.656, \mathrm{df}=19, \mathrm{P}<0.05$ ). 


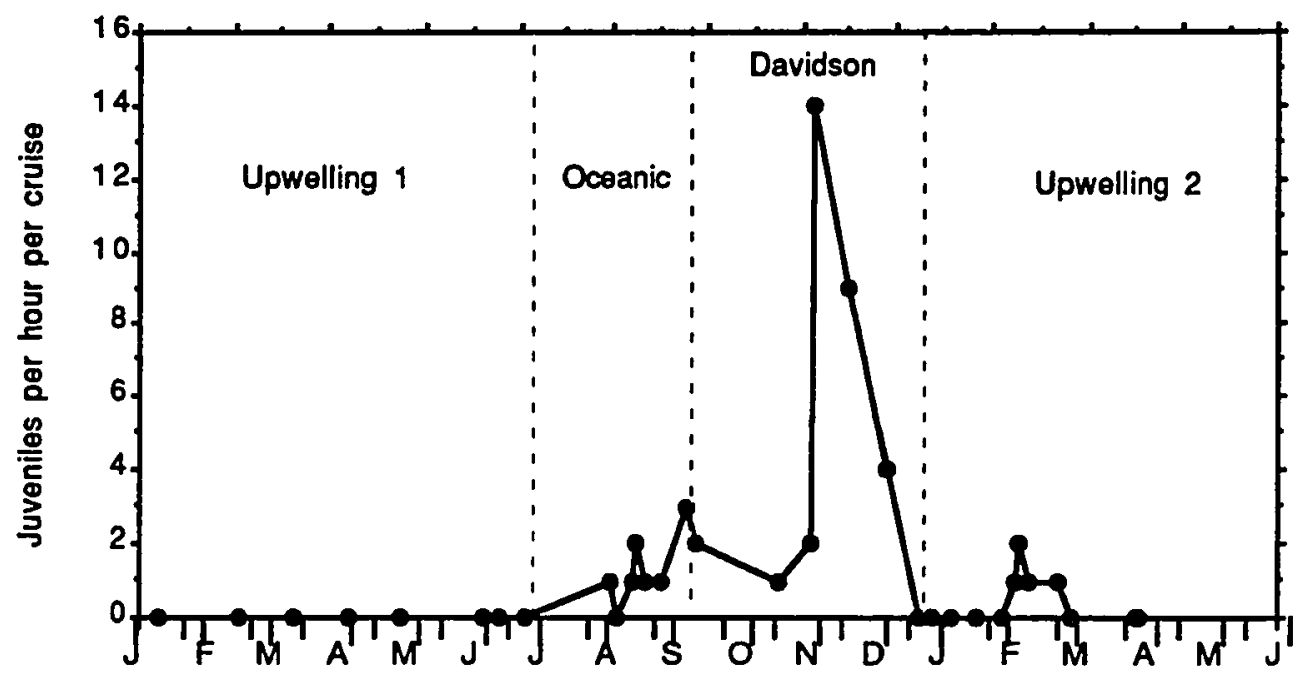

Fig. 8. Juvenile harbor porpoises per hour per cruise varied signigficantly over season $(H=16.693, d f=3, P<0.05)$. 


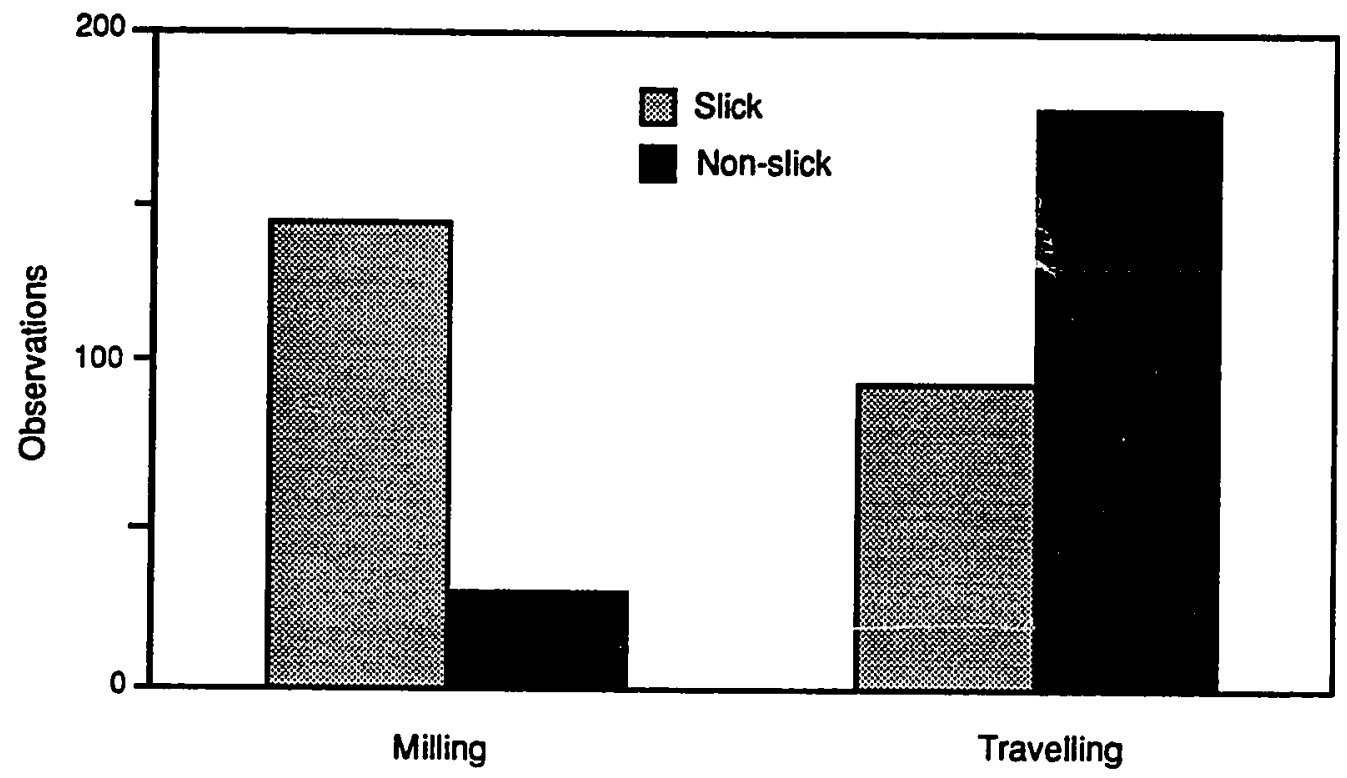

Fig. 9. Milling was observed significantly more often in surface slicks (Chi-square $=10.22, \mathrm{df}=1, \mathrm{p}<0.05$ ), and travelling more often in non-slick areas (Chi-square $=106.33, \mathrm{df}=1, \mathrm{p}<0.05$ ). 


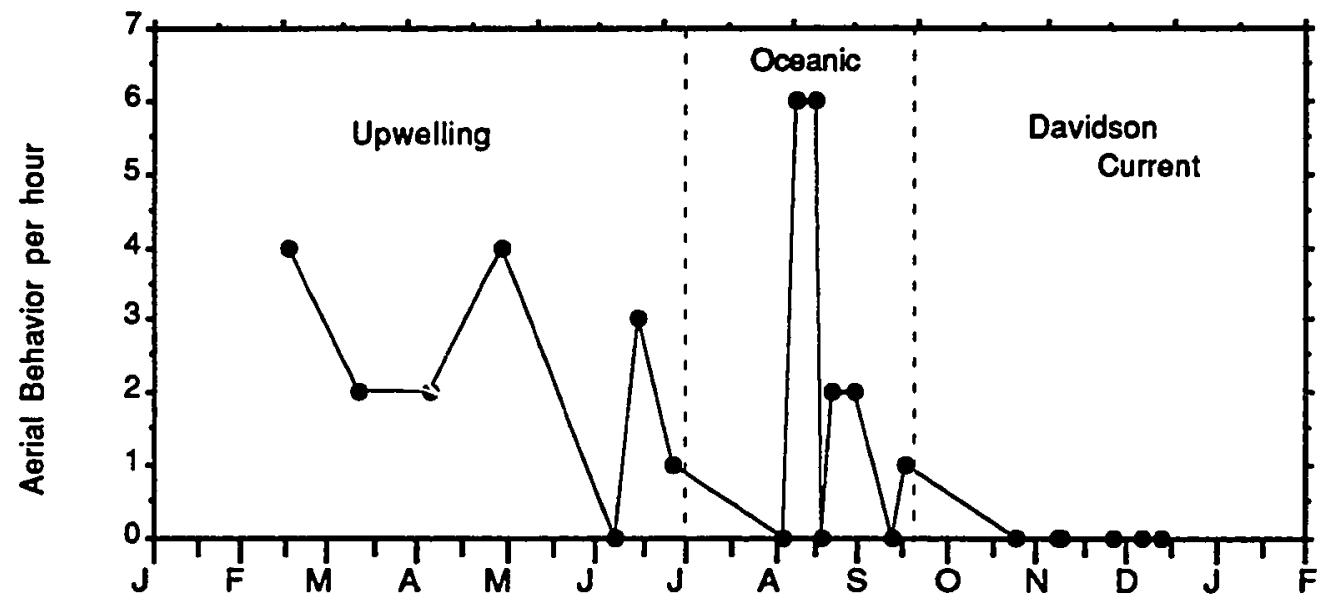

Fig. 10. Aerial behavior per hour fluctuated significantly over time ( $\mathrm{H}=$ 4.746, $\mathrm{df}=3, \mathrm{P}<0.05)$. 


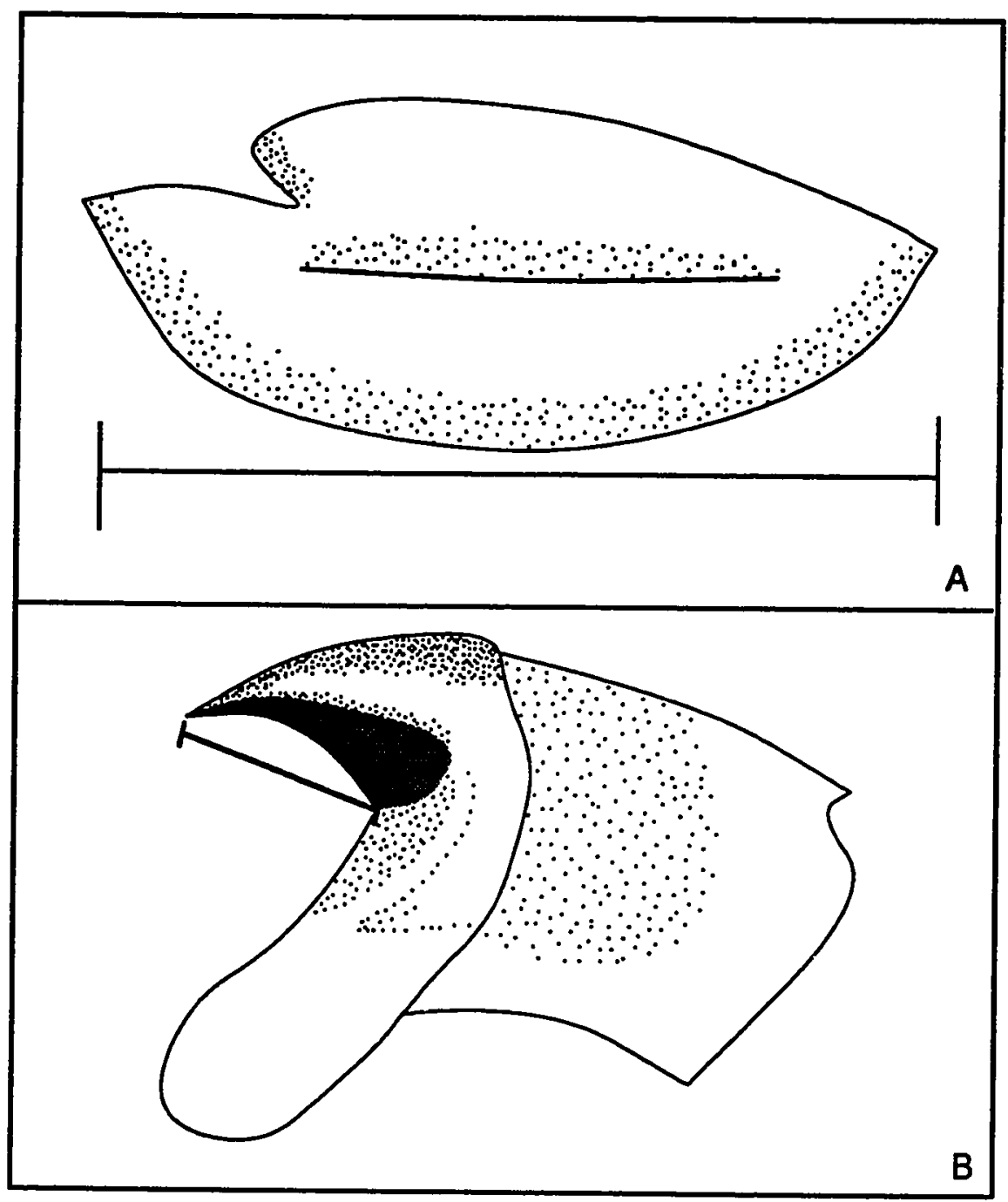

Fig. 11. Longitudinal measurements of otoliths $(A)$ and squid beaks (B, after Clarke 1986) were taken for all found in harbor propoise stomachs. 


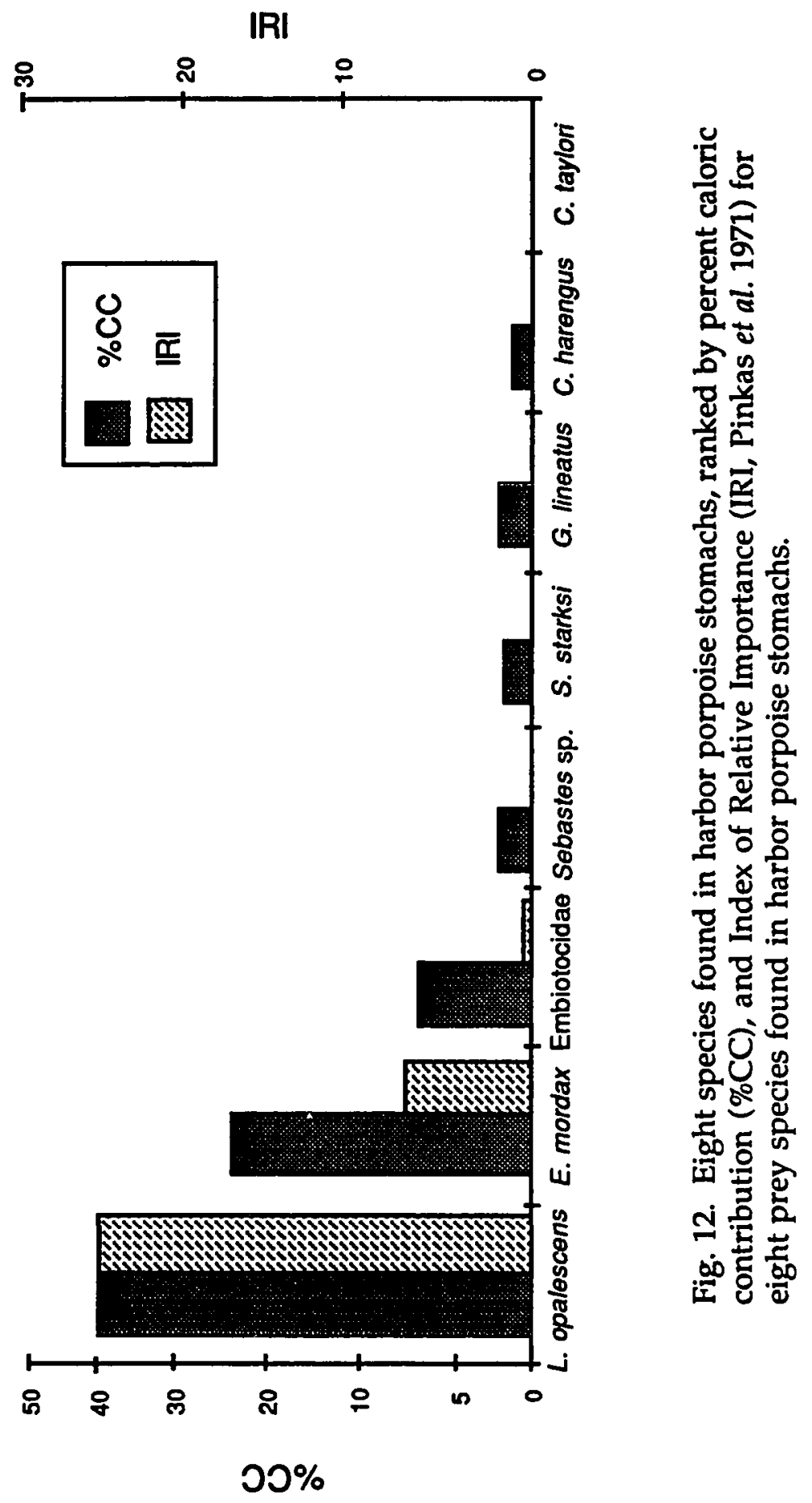


Table 1. Prey consumed by harbor porpoises in this study. $n=19$ stomachs. Where values were unobtainable, substitutions were taken from the taxonomically closest species available. Caloric measurements based on wet weight.

$\begin{array}{llll} & & \text { Mean } & \mathrm{kcal} / \\ \text { Species } & \text { Common Name } & \text { mass }(\mathrm{g}) & 100 \mathrm{~g} \text { \#Stomach }\end{array}$

Engraulis mordax Northern anchovy

18.9

$152 \quad 10$

Loligo opalescens Market squid

26.8

$85 \quad 17$

Chilara taylori Spotted cuskeel

47.0

$\begin{array}{ll}74^{1} & 1\end{array}$

Sebastes sp.

Rockfishes

280.0

83

1

Embiotocidae Surfperches

95.7

$101^{2} \quad 1$

Clupea harengus Pacific herring

34.9

160

2

Spirinchus starksi Night smelt

47.9

$117^{3}$

1

Genyonomus White croaker

200.0

lineatus

1 based on Ophiodon barbatum

2 based on Chromis chromis

3 based on Thaleichthys pacificus

4 based on Umbrina steindachneri 
Table 2. Data on harbor porpoises used in this study. Specimens came from Seascape (Sscp), Pajaro Dunes (PD), Moss Landing State Beach (MLSB), Seacliff State Beach (Sclf SB), Marina State Beach (MSB), Salinas River State Beach (SRSB), Aptos, Santa Cruz Harbor (SCH), Sunset State Beach (SSB) and La Selva Beach (LSB). Standard length in $\mathrm{cm}$.

$\begin{array}{lcllc}\text { Field\# } & \text { Stranding Date } & \text { Cause of Death } & \text { Location } & \text { SL } \\ \text { BEC 89-1 } & \text { 27 Feb 1989 } & \text { Gillnet } & \text { Sscp } & 129 \\ \text { EJD 005 } & -\quad 1988 & \text { Gillnet } & \text { PD } & -- \\ \text { EJD 007 } & \text { 18 Feb 1989 } & \text { Unknown } & \text { MLSB } & 155 \\ \text { EJD 008 } & \text { 28 Feb 1989 } & \text { Gillnet } & \text { MSB } & 135 \\ \text { EJD 009 } & 5 \text { Mar 1989 } & \text { Gillnet } & \text { Sclf SB } & 147 \\ \text { EJD 010 } & \text { 16 Mar 1989 } & \text { Gillnet } & \text { MSB } & 150 \\ \text { EJD 011 } & \text { 25 Mar 1989 } & \text { Gillnet } & \text { SRSB } & 151 \\ \text { EJD 012 } & \text { 4 Mar 1989 } & \text { Gillnet } & \text { MSB } & 147 \\ \text { LML 87-9 } & \text { 27 Oct 1987 } & \text { Unknown } & \text { Aptos } & 171 \\ \text { LML 88-1 } & \text { 14 Mar 1988 } & \text { Gillnet } & \text { SCH } & 141 \\ \text { LML 88-2 } & \text { 14 Mar 1988 } & \text { Gillnet } & \text { SCH } & 130 \\ \text { NAB 007 } & \text { 4 Apr 1989 } & \text { Gillnet } & \text { SSB } & 145 \\ \text { NAB 008 } & \text { 29 Mar 1989 } & \text { Gillnet } & \text { SSB } & 117 \\ \text { NAB 009 } & 5 \text { Apr 1989 } & \text { Gillnet } & \text { SSB } & 156 \\ \text { NAB 010 } & \text { 4 Apr 1989 } & \text { Gillnet } & \text { SSB } & 161 \\ \text { NAB 011 } & 5 \text { Apr 1989 } & \text { Gillnet } & \text { SSB } & 163 \\ \text { NAB 012 } & \text { 5 Apr 1989 } & \text { Gillnet } & \text { MSB } & 132 \\ \text { TAJ 181 } & \text { 15 Feb 1989 } & \text { Gillnet } & \text { PD } & 134 \\ \text { TRK 107 } & 5 \text { Apr. 1989 } & \text { Gillnet } & \text { LSB } & 140 \\ \text { TRK 108 } & \text { 5 Apr 1989 } & \text { Gillnet } & \text { MSB } & 138\end{array}$


Table 3. Percent caloric contribution (\%CC), index of relative importance (IRI), and frequency of occurrence (\%FO) for eight species found in harbor porpoise stomachs ( $n=19$ stomachs).

Species

$\% \mathrm{CC}$

IRI

L. opalescens

46.79

21.080

E. $\operatorname{mordax}$

32.14

6.060

Embiotocidae

11.52

0.446

Sebastes spp.

4.19

0.068

S. starksi

3.19

0.007

G. lineatus

2.85

0.030

C. harengus

1.89

0.028

C. taylori

0.06

0.100 
APPENDIX

Cruise Dates and Objectives.

Objective symbols: $\mathrm{O}=$ observation of abundance and behavior, $\mathrm{P}=$ physical oceanography data collected, $\mathrm{V}=$ validation of boat estimations of number, behavioral state, and sea surface type, with cliff-top observations. 
Appendix. Cruise dates and objectives.

\begin{tabular}{|c|c|c|}
\hline Cruise & Date & Objective \\
\hline 1. & $\operatorname{Jan} 10,1989$ & 0 \\
\hline 2. & Feb 21, 1989 & $O, P$ \\
\hline 3. & Mar 21, 1989 & $O, P$ \\
\hline 4. & Apr 18, 1989 & $O, P$ \\
\hline 5. & May 16,1989 & $O, P$ \\
\hline 6. & Jun 29, 1989 & $O, P$ \\
\hline 7. & Jul 7, 1989 & 0 \\
\hline 8. & Jul 11, 1989 & O,P \\
\hline 9. & Aug 24, 1989 & $O, P$ \\
\hline 10. & Aug 28, 1989 & O,P \\
\hline 11. & Sept 5, 1989 & $0, P$ \\
\hline 12. & Sept 8, 1989 & 0 \\
\hline 13. & Sept 12,1989 & $\mathrm{O}, \mathrm{P}$ \\
\hline 14. & Sept 20, 1989 & 0 \\
\hline 15. & Oct 5, 1989 & $O, P$ \\
\hline 16. & Oct 10,1989 & $\mathrm{O}, \mathrm{P}$ \\
\hline 17. & Nov 8, 1989 & $P$ \\
\hline 18. & Nov 22, 1989 & $O, P$ \\
\hline 19. & Dec 12, 1989 & $\mathrm{~V}$ \\
\hline 20. & Dec 19, 1989 & $\mathrm{O}, \mathrm{P}$ \\
\hline 21. & Dec 20, 1989 & $O, P$ \\
\hline 22. & $\operatorname{Jan} 10,1990$ & $O, P$ \\
\hline 23. & Jan 22, 1990 & $\mathrm{O} P$ \\
\hline 24. & Feb 7, 1990 & $O, P$ \\
\hline 25. & Feb 21, 1990 & $\mathrm{~V}$ \\
\hline 26. & Mar 6, 1990 & $\mathrm{O}$ \\
\hline 27. & Mar 7, 1990 & V \\
\hline 28. & Mar 13, 1990 & 0 \\
\hline 29. & Mar 14, 1990 & 0 \\
\hline 30. & Mar 20, 1990 & 0 \\
\hline 31. & Apr 4, 1990 & V \\
\hline 32. & Apr 10, 1990 & 0 \\
\hline 33. & May 15,1990 & 0 \\
\hline 34. & May 16,1990 & 0 \\
\hline 35. & Jun 5, 1990 & 0 \\
\hline 36. & Jun 6, 1990 & 0 \\
\hline 37, & Jun 7, 1990 & $\mathrm{O}$ \\
\hline 38. & Jun 8, 1990 & 0 \\
\hline
\end{tabular}

